NBER WORKING PAPER SERIES

\title{
HOW IMPORTANT ARE CLASSROOM PEER EFFECTS? EVIDENCE FROM BOSTON'S METCO PROGRAM
}

\author{
Joshua D. Angrist \\ Kevin Lang \\ Working Paper 9263 \\ http://www.nber.org/papers/w9263
NATIONAL BUREAU OF ECONOMIC RESEARCH
1050 Massachusetts Avenue
Cambridge, MA 02138
October 2002

Special thanks go to Andrew Kolesnikov and especially Byron Lutz for outstanding research assistance, and to Sue Picardo and the staff of the Brookline Public Schools data processing unit for help with data. We are grateful to Jean McGuire and her staff at Metco, Inc. for helping us understand the history of Metco and the placement process. Thanks also go to the Upjohn Institute for funding and to seminar participants at Universitat Pomepeu Fabra, the MIT Labor Lunch, and the 2002 NBER Labor Studies meeting for helpful comments. The views expressed in this paper are our own and not necessarily those of any of the individuals or organizations from whose assistance we have benefitted.

(C) 2002 by Joshua D. Angrist and Kevin Lang. All rights reserved. Short sections of text, not to exceed two paragraphs, may be quoted without explicit permission provided that full credit, including (C) notice, is given to the source. 
How Important are Classroom Peer Effects? Evidence from Boston's Metco Program Joshua D. Angrist and Kevin Lang

NBER Working Paper No. 9263

October 2002

JEL No. I2, J7

\begin{abstract}
$\underline{\text { ABSTRACT }}$
Most integration programs transfer students between schools within districts. In this paper, we study the impact of Metco, a long-running desegregation program that sends mostly black students out of the Boston public school district to attend schools in more affluent suburban districts. We focus on the impact of Metco on the students in one of the largest Metco-receiving districts. In the 2000 school year, Metco increased the proportion black in this district from about 7.5 percent to almost 12.5 percent. Because Metco students have substantially lower test scores than local students, this inflow generates a significant decline in scores, with an especially marked effect on the lower quantiles. The overall decline is due to a composition effect, however, since OLS estimates show no impact on average scores in the sample of all non-Metco students. On the other hand, OLS and fixed effects estimates show some evidence of an effect on the scores of minority 3rd graders in reading and language. Instrumental variables estimates for 3rd graders are imprecise but generally in line with OLS. Further analysis shows the negative effects on 3rd graders to be clearly present only for girls. Given the highly localized nature of these results, we conclude that any peer effects from Metco are modest and short-lived.
\end{abstract}

Joshua D. Angrist

MIT

Department of Economics

50 Memorial Drive

Cambridge, MA 02142

and NBER

angrist@mit.edu
Kevin Lang

Boston University

Department of Economics

270 Bay State Road

Boston, MA 02215

and NBER

lang@bu.edu 
Few questions in American public life are as controversial as the social consequences of school integration. Policy makers and researchers have debated the impact both on the individual students who are bused to school for the purposes of racial balance, and on residential patterns in school districts affected by busing. Even the proximate impact of desegregation efforts have not been clear cut. The Supreme Court's 1955 Brown II decision ambitiously declared that schools should be integrated "with all deliberate speed," but in many districts integration was slow and incomplete. Integration policies nevertheless appear to have been at least partly successful, in the sense that these policies increased the probability that white and black students study togther (Welch and Light, 1987: Rosell and Armor, 1996). Moreover, research by labor economists strongly suggests that the end of de jure segregation led to substantial economic gains for blacks. ${ }^{1}$

Busing programs typically send black students to schools that were previously all-white and vice versa, often in the face of resistance from local school boards and other elected officials. In an influential paper, Coleman (1975) argued that court-ordered busing accelerated white's exodus from central cities, sparking a literature looking at the impact of desegregation efforts on racial mixing in schools. Few studies, however, have looked at the impact of desegregation on the primarily white students who remain in the schools to which black students are bused, i.e. on the students in schools where the percentage minority increased as a consequence of busing. ${ }^{2}$ In this paper, we use the Boston area Metropolitan Council for Educational Opportunities (Metco) desegregation program to study the impact of busing on students in schools to which the Metco students were bused.

The Metco program, one of the largest and longest-running desegregation programs in the US, is unusual in that it sends mostly black students out of the Boston district into schools in the surrounding, mostly white, suburban districts. In contrast with court-ordered desegregation efforts, Metco is voluntary on the part of both the families of students being bused and the school districts receiving the bused students.

\footnotetext{
${ }^{1}$ See, e.g., Smith and Welch (1989) and Card and Krueger (1992).

${ }^{2}$ An exception is Guryan (2001), who looks at the impact of court-ordered busing on white and black dropout rates. Clotfelter (1999) is a recent study of white flight.
} 
Metco has not been associated with white flight. In 1970, four years before the 1974 Federal court decision that imposed busing within the Boston district, 29 Metco-receiving districts enrolled almost 1400 students. In the 2000-2001 school year, almost 3,200 Metco students attended school in 32 suburban districts. Metcoreceiving districts were and have remained relatively affluent suburban communities with growing populations. In many of these districts, Metco students account for the majority of minority students. These factors suggest that Metco provides a useful laboratory for the study of the impact of desegregation on students in host districts.

Our study focuses on the impact of Metco on the test scores of $3^{\text {rd }}, 5^{\text {th }}$, and $7^{\text {th }}$ graders in the Brookline Public Schools, one of the largest Metco-receiving districts. The Brookline experience is of historical interest since the Metco program was initiated by a group of Brookline civil rights activists. Along with representatives from nine other school districts, Brookline School Committee member and MIT professor Leon Trilling helped design the Metco program. While Brookline has one of the best school systems in the state, it also has a substantial minority and immigrant population. This fact allows us to assess the impact of Metco on different groups in the receiving district.

In addition to providing an evaluation of the impact of Metco on students in Brookline schools, the results presented here may shed light on more general questions regarding the school environment and peer effects. As noted above, Metco substantially increases the minority population in schools in the receiving districts. In addition, because Metco students have lower average test scores than suburban students, the Metco program lowers average scores in the district. The relatively low scores of Metco students, a fact noted by Metco critics, is politically significant in Massachusetts, where schools and districts are evaluated on the basis of average test scores. More importantly, the increased presence of lower-performing students in suburban districts may adversely affect students resident in the district if peer performance and/or racial 
composition matters for student learning, a possibility explored in a large empirical literature. ${ }^{3}$

The next section provides additional background on Metco and the Brookline school district. Following this, Section II describes the data used here and presents descriptive statistics characterizing Metco's impact on the school environment. Section III discusses OLS and fixed-effects estimates of the effect of Metco on the test scores of non-Metco students. In section IV, we report the results of an instrumental variables (IV) strategy for estimating the effect of Metco. Section V concludes with an assessment of the case for negative peer effects in the Metco program. There is some evidence of a negative effect on the scores of minority $3^{\text {rd }}$ grade girls in some subjects. But the highly specific nature of this result suggests that negative peer effects, if any, are modest and short-lived.

A noteworthy limitation of our study is the narrow focus on achievement as measured by test scores. In particular, we have no information on the effect of Metco on racial attitudes and present only parenthetical evidence suggesting a positive effect on the academic performance of the Metco pupils themselves. A careful analysis of these issues is a prerequisite for a full evaluation of the program. Nevertheless, our results support the view that there are no long-term effects on the academic performance of students in the receiving district, a key concern in the Metco-policy debate.

\section{The Metco Program}

\section{A. Background}

The birth of Metco was an important chapter in the battle over school desegregation in Boston. ${ }^{4}$ In 1963 and 1964, black parents boycotted Boston schools for failing to integrate and, in 1974, Boston school assignment was taken over by a Federal district judge after a protracted legal struggle. Against this backdrop,

\footnotetext{
${ }^{3}$ Recent examples include Boozer, Krueger, and Wolkon, 1992; Hoxby, 2000; Kain, Hanushek, and Rivkin, 2002; Rivkin, 2000).

${ }^{4}$ This section draws on Batson and Hayden (1987) and Metco (1970).
} 
the Brookline Civil Rights Committee approached the Brookline School Committee in 1964 to request that black students from Boston be enrolled in the Brookline Public Schools. In the first half of 1966, the Brookline, Lexington, Newton, Wellesley, Braintree, Lincoln and Arlington School Committees agreed to accept two hundred twenty students the following year. By 1970, twenty-nine suburban school districts had enrolled 1,361 Metco students. Four of these districts later abandoned Metco, but 7 districts joined the program. $^{5}$ Metco-participating districts in the 2000-2001 school year, along with the number of Metco students and the proportion minority in each district, are indicated on the enclosed map. Five percent of the Boston district, or roughly 3,200 students, participate in Metco, and Metco students account for a substantial fraction of the black and Hispanic students in most receiving districts.

Boston parents who are interested in Metco place their child on a waiting list. Every year, Metco coordinators in suburban districts notify METCO, Inc. of the number of openings they have for the following year at each grade level. Applicants are selected from the waiting list on a first-come first-served basis. Boston parents do not get to chose the suburban district where their child is placed although they may refuse a placement. The waiting time for kindergarten entry is about 5 years and placement typically becomes more difficult as grade advances. The state provides funding to districts that accept Metco students according to a formula determined by legislators and the Massachusetts Department of Education. Today, state Metco funding hovers around $\$ 2,800$ per student, plus transportation costs, considerably below average per-student expenditure in the state and less than provided by a state-wide school-choice program. ${ }^{6}$

The Metco program remains controversial. There is a long waiting list and most suburban districts still express strong support. But some Boston educators worry that Metco pulls relatively motivated or high-

\footnotetext{
${ }^{5}$ Hamilton-Wenham, Milton, Dover, and Sherborn dropped out, though Dover-Sherborn, a joint high school district, continues to enroll Metco students.

${ }^{6}$ Under the state's school choice law, school districts that participate in the school choice program receive $75 \%$ of costs, up to a limit of $\$ 5000$ for students in regular, bilingual, or occupational education programs. The tuition rate is $100 \%$ of costs for special education students. Transportation costs are paid by participating families.
} 
achieving students out of the Boston Public Schools. Others believe Metco's focus on race is anachronistic (Tye, 1995a). Metco also generates controversy in some receiving districts. Critics argue that Metco is costly, pulls down average test scores (a factor of increasing importance since Massachusetts introduced mandatory state-wide testing), and negatively influences local students. In 1990, for example, the Lincoln School Committee held a forum on Metco in response to concerns about costs, behavior problems, and the time spent by teachers with Metco children (Cohen, 1990). Lincoln's Metco participation continues to be high at about $13 \%$ of enrollment, but this is down from a target of $20 \%$ established in 1975 . More recently, the Lynnfield School Committee voted to withdraw from Metco in the wake of concerns that "minority students are not being helped and are dragging down the rest of the school" (Vigue, 1999). The Lynnfield decision was unpopular and later reversed.

Despite strong public interest in the Metco program, there is little quantitative evidence on the effect of Metco participation on the students commuting daily from Boston. This largely reflects the difficulty of finding an appropriate comparison group for Metco students. Although METO students are more likely to graduate from high school than are other Boston public school students, Metco students might well have had more favorable outcomes in any event. ${ }^{7}$ On the other side of the Metco equation, there has been almost no research on the impact of Metco participation in receiving districts, other than policy reviews of the sort mentioned above. ${ }^{8}$

${ }^{7}$ Two early largely descriptive studies are Boardman and Brandt (1968) and Clarke (1975), who interviewed Metco parents. Orfield, et al (1997) also surveyed Metco parents. More recently, Eaton (2001) discusses interviews with adults who participated in Metco. These studies establish that most participants strongly believe they benefitted from the program but were not designed to measure whether outcomes were improved for participants. Armor (1972) compared Metco participants with a small number of non-participating siblings. Recently, Elliott (1998) surveyed Metco graduates and a small comparison group, looking at the effect of Metco participation on high school graduation and college attendance. These studies suffer from lack of a good control group, and/or incomplete follow-up of applicants and controls. A small randomized study of the impact of a desegregation program in Hartford is discussed in Crain and Strauss (1985).

${ }^{8}$ Jaggia and Tuerck (2000) estimate the relation between district-level MCAS scores and a range of variables, including percent Metco in district. They find a positive association between percent Metco and scores, but this seems likely to be due to the fact that Metco-receiving districts are among the best in the state. 


\section{B. Metco in Brookline}

Brookline has about 6,000 public school students attending eight elementary schools with grades kindergarten through eight and a single high school. Students generally attend neighborhood schools unless they participate in a district-wide bilingual program. The Brookline School Committee has a long-standing policy and a contractual agreement with the teachers' union to cap class size at twenty-five. This is accomplished by opening new classes where needed.

The Brookline school district is affluent relative to Boston, but much more heterogeneous than most suburban districts. Roughly 10\% of Brookline students are black (including Metco students), 17\% are Asian and $4 \%$ are Hispanic. Typically, $10 \%$ are designated limited-English-proficient (LEP) and $12 \%$ qualify for a free or reduced-price lunch. More than 30\% come from homes in which English is not the first language. Brookline also has a significant transient population with more renters than owners, yet maintains its reputation as one of the best school systems in the state. Brookline students consistently do well on national and state tests, have low dropout rates and a high probability of college attendance.

As noted in the introduction, Brookline has a long-standing connection with the Metco program. Under its current Metco participation agreement, Brookline enrolls 300 Metco students each year, about 5\% of total enrollment in the district. According to school administrators, Metco students are initially assigned to classes where class size is anticipated to be small. Once a Metco student is assigned to a particular Brookline school, transfer to a new school is highly unusual.

\section{Metco and the School Environment}

\section{A. Data and Descriptive Statistics}

Achievement is measured here using the Iowa Test of Basic Skills (ITBS) for $3^{\text {rd }}, 5^{\text {th }}$ and $7^{\text {th }}$ graders. ITBS tests were administered in March 1995 and March 1996 and then in November of each year after that. Data are available for the 1994-2000 school years. In principle, all students except LEP or those with severe 
special needs are tested. Parents may request that their child not be tested but such requests are rare. Our analysis uses test scores reported as the national percentile rank (NPR), which measures achievement relative to the score distribution in a 1992 reference population.

For the purposes of this analysis and to assist the Brookline Schools with other evaluation efforts, ITBS scores were linked with administrative data on student characteristics. This provides information such as sex, race, and whether the student was a Metco student. Also included was programmatic information such as whether students participated in an English as a second language/transitional bilingual English (ESL/TBE) program or a special education program, and school characteristics such as enrollment in the grade, number of classes in the grade and Metco enrollment in the grade.

Table 1 presents descriptive information for the Brookline school system. A typical grade has close to 500 students with an average class size of 20-21. Third and fifth grade classes are largely self-contained except for special classes (e.g. art, physical education) so the class sizes for these grades represent the typical number of students in the class for core subjects. For $7^{\text {th }}$ grade students, the reported number of classes is the number of "home rooms" and therefore a less accurate measure of class size for core subjects.

The proportion of students taking the ITBS ranges from a low of $79 \%$ among $5^{\text {th }}$ graders in 1995 to a high of $95 \%$ among $7^{\text {th }}$ graders in 1998. Special education and LEP students (in ESL/TBE programs) account for most of those who do not take the test. In particular, special education students with an individualized education plan (IEP) that exempts them from taking standardized tests do not take the ITBS. The remainder of those not tested consist of students who were ill or whose parents requested that they not take the exam. Most of the variation in the proportion tested comes from efforts by school administrators to increase the participation of special education students and from fluctuation in the number of special education and LEP students. Variation in ESL/TBE participation across grades reflects the fact that most Brookline students spend only one or two years in ESL or TBE programs. 
The percentage of students enrolled in special education programs averages somewhat below $20 \%{ }^{9}$ On the other hand, there has been a steady increase in the fraction of special education students tested. For example, in 1996, special education students accounted for 8 percentage points of the almost $19 \%$ of $3^{\text {rd }}$ graders not tested. By the 2000 school year, special education students accounted for only about 4.5 percentage points of the $3^{\text {rd }}$ graders not tested.

We use two different measures of the proportion Metco. The first is an estimate of the proportion of all students in a school, grade, and year from Metco. The second is the proportion of tested students from Metco. Although Metco status is reasonably well measured from 1996 forward, both measures rely on incomplete information for the 1994 and 1995 school years, for which Metco status must be inferred from a variety of sources. The proportion Metco varies from a low of $2.6 \%$ in 1995 in $3^{\text {rd }}$ grade to a high of $7.4 \%$ in 1997 in $7^{\text {th }}$ grade. Metco students generally represent a higher proportion of tested students than they do of all students because few Metco students are LEP or have severe special needs. Consistent with the program's historical emphasis on desegregation, Metco students are overwhelmingly black. Hispanics constitute the second largest Metco ethnic group, followed by a small number of Asians. Metco students are also more likely to be female than male. ${ }^{10}$

Table 2 reports the proportion of Metco students in total enrollment by grade, school, and year. The table, which orders school from lowest to highest proportion Metco in each year, documents the considerable variability in the proportion Metco across schools and over time. Nineteen of the 144 grade/school/year combinations had no Metco students. At the other extreme, at one school over one-fifth of $7^{\text {th }}$ graders in 1998 were Metco students, and of the 18 possible grade/year combinations, in 12 cases, there are at least two schools where the proportion Metco was at least 9 percent of enrollment.

${ }^{9}$ This excludes children in out-of-district placements. Special education status is unavailable for the first two years in the sample but can be determined for students who remained in the school system after 1995 .

${ }^{10}$ Anecdotal evidence suggests Metco girls stay in the program longer than boys (Tye, 1995b). 
Not surprisingly given the relatively high average family income in Brookline and the reputation of the school system, Brookline students generally perform well on the ITBS. As shown in Table 3, the average core among non-Metco students NPR is 72 for $3^{\text {rd }}$ and $5^{\text {th }}$ graders and 76 for $7^{\text {th }}$ graders. Test scores by subject are similarly high, although language scores tend to be slightly lower than the overall scores, possibly reflecting the high proportion of non-native English speakers. There is also a significant racial gap for Brookline residents, with the average score for blacks around the overall national median $\left(51^{\text {st }}, 50^{\text {th }}\right.$ and $55^{\text {th }}$ percentiles in the three grades) while the scores of whites are around the top quartile $\left(74^{\text {th }}, 75^{\text {th }}\right.$ and $80^{\text {th }}$ percentiles in the three grades). The standard deviation of test scores ranges from 22-26 points, depending on grade and subject. The standard deviation of school/year cell averages is naturally much smaller, in the 5-7 range.

Among Brookline residents, the average NPR is almost one point higher for $5^{\text {th }}$ graders than for $3^{\text {rd }}$ graders and 4 points higher for $7^{\text {th }}$ graders than $5^{\text {th }}$ graders. Since the ITBS is normed to a national standard for each grade, this relative advancement suggests that a Brookline education increases student achievement more than most school systems. Of course, this might also reflect differential selection, reflecting a process whereby Brookline $7^{\text {th }}$ graders are more favorably selected than $3^{\text {rd }}$ and $5^{\text {th }}$ graders.

\section{B. Scores of Metco Students}

Metco students have test scores significantly below those of Brookline residents. ${ }^{11}$ The average core NPR is about 22 points lower for Metco students, a gap almost as large as the standard deviation of test scores among Brookline students. On the other hand, black students in the Metco program have scores broadly similar to those of blacks from Brookline, while non-black Metco students, who are mostly Hispanic and Asian, have scores between those of non-Metco Hispanics and Asians.

\footnotetext{
${ }^{11}$ Children of town employees may attend Brookline schools regardless of where they live, and there are a small number of (mostly foreign) students who pay tuition through a variety of programs. These groups are included in our sample of Brookline residents.
} 
Despite the gap in scores by Metco status, Table 3 suggests that Metco students benefit from time in the Metco program. In particular, Metco students generally show more improvement between $3^{\text {rd }}$ and $7^{\text {th }}$ grades than do Brookline residents. Again, it is possible that this reflects more favorable sample selection for older Metco students than for younger Metco students, but the simplest explanation is that the Brookline Metco program raises the achievement of participants. Of course, the ideal evaluation strategy for assessing the value of Metco for participants would use comparisons with an otherwise similar group of non-Metco students from Boston.

\section{Effect on the School Environment}

The differences in average achievement between resident and Metco students are large enough for Metco participation to reduce average test scores in Brookline. This can be seen in Table 4. In particular, Columns 1-8 report estimates of

$$
\bar{y}_{\mathrm{gjt}}=\alpha_{\mathrm{g}}+\beta_{\mathrm{j}}+\gamma_{\mathrm{t}}+\delta m_{\mathrm{gjt}}+\lambda s_{\mathrm{gjt}}+\mathrm{u}_{\mathrm{gjt}}
$$

where $\overline{\mathrm{y}}_{\mathrm{gjt}}$ is the average score in the grade $\mathrm{g} / \mathrm{school} \mathrm{j} / \mathrm{year} \mathrm{t}$ cell. $s_{\mathrm{gjt}}$ is class size in the cell, including Metco, and $m_{\mathrm{gtt}}$ is percent Metco [where $\mathrm{g} \times \mathrm{j} \times \mathrm{t}=3 \times 8 \times 7=168$ cells]. The results in the upper panel show estimated effects of percent Metco enrolled and the lower panel shows estimates of coefficients on percent Metco tested. The leftmost columns show unweighted estimates, while the middle columns shows estimates weighted by the number of students tested in the cell. Columns 9-12 report the result of treating individual students as the unit of observation and replacing $\bar{y}_{\mathrm{gjt}}$ with $\overline{\mathrm{y}}_{\mathrm{gt}(\mathrm{i})}$, the average score of students in the cell, excluding student i. These estimates capture the effect of percent Metco on non-Metco students' peer means since Metco students are included in $\bar{y}_{\text {gitti }}$ but excluded from the estimation sample. ${ }^{12}$

The estimates tell a similar story for both Metco regressors and all three estimation strategies. The

\footnotetext{
${ }^{12}$ Standard errors in columns 9-12 are adjusted for cell-clustering. All models include a set of cohort effects (for 11 grade/year cohorts). Models using micro-data include dummies for sex and race.
} 
presence of Metco students has a marked negative effect on the average performance of the class. Increasing the number of Metco students by ten percentage points (about two per class) lowers average performance by about $2 \frac{1}{2}$ percentage points, or about 40 percent of the standard deviation of the group averages. This does not imply that the presence of Metco students has a negative causal effect on non-Metco students, however. As we show below, the estimated effect of percent Metco on average peer performance is consistent with a pure composition effect arising from the large gap between the scores of Metco and nonMetco students.

Because Metco students' scores are concentrated in the lower tail of the Brookline residents' score distribution, the percent Metco shifts the overall score distribution most sharply in the lower tail. To illustrate this point, Table 5 shows the effect of percent Metco on the .2 quantile ( $2^{\text {nd }}$ decile) of the score distribution in each cell, denoted $\mathrm{q}_{\mathrm{gjt}}^{2}$. The estimates in columns $1-8$ were constructed by replacing $\overline{\mathrm{y}}_{\mathrm{gjt}}$ with $\mathrm{q}_{\mathrm{gjt}}^{2}$ in equation (1), while columns 9-12 report quantile regression estimates using micro data. The estimates in column 9 suggest that, on average, increasing the proportion Metco from 0 to 10 percent lowers the second decile of the core NPR score distribution by 4-6 points.

The results in Table 5, like those in Table 4, may simply reflect the fact that Metco students have lower scores than Brookline residents on the ITBS. But the magnitude of this decline is important for other reasons as well. First, previous research suggests a strong negative correlation between individual achievement and the achievement levels of peers in the classroom. While the proper interpretation of this correlation is disputed, it may indicate negative peer effects. ${ }^{13}$ The effect of percent Metco on average scores is large enough that increases in percent Metco may induce a negative peer effect that should be evident in our data if the effect is large enough. Second, increasing the number of students at the bottom of the achievement distribution may have an especially adverse impact on other students if, for example, classroom

\footnotetext{
${ }^{13}$ For references to empirical studies and a recent theoretical model of peer interactions in education see Lazear (2001). For a skeptical look at peer effects, see Evans, Oates, and Schwab (1992).
} 
instruction is targeted at low-achievers or if low-achieving students are more likely to be disruptive or require more of the teacher's attention. Since percent Metco pulls down the lower tail of the score distribution, again there would seem to be scope for negative peer effects.

Another aspect of the relation between percent Metco and the Brookline school environment, not described in Tables 4 and 5, is the impact on racial composition. A number of authors have found a negative association between percent minority in schools or classes and academic performance, particularly for minority students. The mechanism behind this effect is unclear since percent minority is presumably a proxy for a variety of economic and social differences. In any case, increasing the proportion Metco sharply increases the proportion minority in Brookline schools; indeed the "first-stage effect" of percent Metco on percent minority is close to one. As with peer effects that operate through test scores, any effects of school composition may also be detected through an analysis of Metco.

\section{The Impact on non-Metco Students}

\section{A. OLS Estimates}

We estimated the effect of Metco students on the achievement of non-Metco students using two models similar to those used to construct the estimates in Table 4. The first set of estimates is from a regression of the average NPR of non-Metco students on the proportion Metco in a grade, school, and year. The regression includes grade, school, and year main effects, as well as controls for class size:

$$
\overline{\mathrm{y}}_{\mathrm{gjt}}^{*}=\alpha_{0 \mathrm{~g}}+\beta_{0 \mathrm{j}}+\gamma_{0 \mathrm{t}}+\delta_{0} m_{\mathrm{gjt}}+\lambda_{0} s_{\mathrm{gjt}}+\eta_{\mathrm{gjt}}
$$

where $\bar{y}_{\mathrm{gjt}}^{*}$ is the average score in the cell, omitting Metco kids. The model includes controls for cohort when grades are pooled since some students are observed more than once. Equation (2) was estimated without weighting, since weighted estimation generates the same results as estimation using micro data if there are no student-level controls.

The second approach uses micro data and adds controls for student characteristics. The regression 
model in this case can be written:

$$
\mathrm{y}_{\mathrm{gjti}}=\alpha_{0 \mathrm{~g}}+\beta_{0 \mathrm{j}}+\gamma_{0 \mathrm{t}}+\delta_{0} m_{\mathrm{gjt}}+\lambda_{0} s_{\mathrm{gjt}}+\mathrm{X}_{\mathrm{i}}{ }^{\prime} \Gamma_{0}+\epsilon_{\mathrm{gjt}}
$$

where $\mathrm{X}_{\mathrm{i}}$ is a vector of race, sex, special education and TBE/ESL dummies and $\epsilon_{\mathrm{gjti}}$ is an individual random error term. As in (2), the model includes cohort dummies when grades are pooled.

The standard errors for the micro model were adjusted for clustering using the formula in Liang and Zeger (1986), i.e., the procedure implemented by the Stata cluster command. In practice, the standard errors from this procedure may be misleading, especially when there are few clusters, and inference using grouped data has been shown to be more reliable (see, e.g., Feng, et al, 2001; or Donald and Lang, 2001). This leads us to reported results using both cells and individuals. Unadjusted standard errors for the micro estimates are also reported for purposes of comparison. Both the grouped and micro equations use the percent Metco tested for $m_{\mathrm{gjt}}$ since this is more consistently measured and probably more accurate than the percent Metco enrolled (though estimates using percent enrolled are similar).

Pooled estimates of equation (2) show small positive, but insignificant, effects of percent Metco on average non-Metco scores in each subject. This can be seen in the first four columns of Panel A in Table 6. The estimates using micro-data, reported in columns 5-8, are negative but again small and insignificant, suggesting that the proportion Metco has no effect on non-Metco students. On the other hand, it should be noted that the standard errors for the micro-data estimates in column 5 are such that the smallest negative effect that could be detected (i.e., the effect that would be significant at the $5 \%$ level in a one-tailed test) is about $5.9 \times 1.64=-9.7$. Since the effect of percent Metco tested on peer means is -24 (see column 9 in Table 5), the smallest detectable peer effect that operates solely through the test scores of all classmates is therefore about .4. On the other hand, if the lower tail of the score distribution matters for achievement, then peer effects as small as .2 would be significant.

Previous research on peer effects reports estimates in the range of detectable effects based on the standard errors reported in Table 6, but smaller effects cannot be ruled out. For example, using data from 
Texas, Hoxby (2000) reports estimates of the effect of the average peer score ranging from .1 to .55. Our estimates for Brookline rule out the high end of these effects but not the low end. It bears emphasizing, however, that previous research reports estimates of peer effects that are not fully captured by differences in test scores. For example, Hanushek, et al (2002), also using data from Texas schools, report large effects of racial composition that do not appear to be driven by the achievement differences of classmates.

Earlier analyses also suggest that peer effects may be especially important within racial groups. For example, black students may interact more with other blacks. Since Metco students are mostly black and Hispanic, this motivates an analysis in samples limited to minority students from Brookline, about $10.5 \%$ of the resident students tested.

Estimates for minority residents of Brookline, reported in Panel B for blacks and Hispanics, and Panel C for blacks only, show no significant Metco effects on $5^{\text {th }}$ and $7^{\text {th }}$ graders, but some of the estimates for $3^{\text {rd }}$ graders are negative and significant. The microdata estimates in column 6 are probably more reliable since these control for individual student characteristics such as race (when blacks and Hispanics are pooled), sex, special education status, and ESL/TBE status. These estimates show significant negative effects on reading and language scores for blacks and Hispanics, and significant negative effects for all scores except math for blacks. The difference between panels B and $\mathrm{C}$ suggest that the negative effect is coming primarily from the impact on blacks. The estimated effects are such that adding a Metco student to a class (i.e., going from 0 to about $5 \%$ Metco) is expected to reduce black test scores by 8-9 points, or .3 of the standard deviation of the score distribution for black $3^{\text {rd }}$ graders who live in Brookline.

The effects on black students cannot be easily explained by a traditional peer effect that operates solely through test scores since Table 5 suggest that increasing percent Metco by 5 percentage points reduces average test scores among peers by only about 1.25 points. Effects a large as those in Panel C may therefore signal some sort of endogeneity problem or omitted variables bias. On the other hand, this result could be explained by a localized peer effect where additional Metco students displace relatively high-scoring and 
high-SES resident students in a minority student's immediate peer group. Moreover, as noted above, peer effects need not operate solely through test scores. The fact that the negative effects appear for language and reading is also consistent with Eaton's (2001) account of Metco, since some Metco students reported differences in speech patterns to be a major hurdle in adapting to the suburban environment. ${ }^{14}$ But the fact that negative estimates are limited to the $3^{\text {rd }}$ grade sample and absent for Math scores also suggests these effects may be spurious or at least dissipate quickly.

\section{B. Fixed-Effects Estimates}

Control for unobserved individual effects provides an initial check on the OLS estimates. To implement the fixed effects strategy, we limited the sample to students observed in both $3^{\text {rd }}$ and $5^{\text {th }}$ grades or $5^{\text {th }}$ and $7^{\text {th }}$ grades (about $40 \%$ of the pooled sample) $)^{15}$ and estimated the following grade-differenced model,

$$
\begin{aligned}
\mathrm{y}_{\mathrm{gjti}}-\mathrm{y}_{\mathrm{g}+2, \mathrm{j}, \mathrm{t} 2, \mathrm{i}} \equiv \nabla \mathrm{y}_{\mathrm{gjti}}= & \left(\beta_{\mathrm{gj}}^{*}-\beta_{\mathrm{g}+2, \mathrm{j}}^{*}\right)+\left(\gamma_{\mathrm{g}, \mathrm{t}}^{*}-\gamma_{\mathrm{g}+2, \mathrm{t}+2}^{*}\right) \\
& +\left(\delta_{\mathrm{g}}^{*} m_{\mathrm{gjt}}-\delta_{\mathrm{g}+2}^{*} m_{\mathrm{g}+2, \mathrm{j}, \mathrm{t}+2}\right)+\left(\lambda_{\mathrm{g}}^{*} S_{\mathrm{gjt}}-\lambda_{\mathrm{g}+2}^{*} S_{\mathrm{g}+2, \mathrm{j}, \mathrm{t}+2}\right)+\nabla \epsilon_{\mathrm{gjt}},
\end{aligned}
$$

where $\beta_{\mathrm{gj}}^{*}$ and $\gamma_{\mathrm{g}, \mathrm{t}}^{*}$ are grade-specific school and year effects, and $\delta_{\mathrm{g}}^{*}$ and $\lambda_{\mathrm{g}}^{*}$ are grade-specific Metco and classsize effects. Differencing in this case means either a change from $g=3^{\text {rd }}$ grade to $g+2=5^{\text {th }}$ grade or a change from $g=5^{\text {th }}$ grade to $g+2=7^{\text {th }}$ grade. ${ }^{16}$ Estimates were computed separately for each pair of differences, with and without the restriction that Metco and class size effects are the same across grades. Not that without this restriction we obtain two estimates of the effect on $5^{\text {th }}$ graders, depending on whether the contrast is with $3^{\text {rd }}$

${ }^{14}$ Bethel (1999) recounts the concerns of upper middle class black parents from Concord, an affluent Metcoreceiving suburb of Boston. These parents worry about negative examples and a tendency of some of their children to affect "a certain street savy style and language" when mixing with poorer blacks.

${ }^{15}$ The sample size falls because $5^{\text {th }}$ and $7^{\text {th }}$ graders in 1994 and 1995 cannot be match with prior years and $3^{\text {rd }}$ and $5^{\text {th }}$ graders in 1999 and 2000 cannot be matched with later years, and because students enter and leave the Brookline system. The maximum theoretical match rate is about 70 percent.

${ }^{16}$ All but a handful of students observed more than once advanced grades between observations. Multiple observations on a student in the same grade were averaged. These students have different year effects than those who advanced on schedule. 
or $7^{\text {th }}$ graders.

The fixed-effects estimates are generally in line with the OLS. This can be seen in Table 7, which reports estimates for the sample of all races and for black students only. Further empirical results for the sample of blacks and Hispanics are omitted since they primarily reflect the results for blacks. Results for all non-Metco pupils show no effects, whether estimated in models pooled across grades or separately. Not surprisingly, however, the fixed effects estimates are not as precise as those in Table 6.

In contrast with the estimates in Panel A, those for blacks only, reported in Panel B, show some evidence of negative effects on $3^{\text {rd }}$ grade pupils. For example, the coefficient on percent Metco in the model for $3^{\text {rd }}$ grade scores is about -216 (unclustered s.e.=103), not far from the corresponding OLS estimate of 170. One difference between the results in Table 7 and those in Table 6 are the negative and significant estimates for $5^{\text {th }}$ grade Math scores, and the generally larger estimates for $5^{\text {th }}$ graders. This result is not very robust, however, since it appears only in column 3 , when the contrast is between $3^{\text {rd }}$ and $5^{\text {th }}$ grade, and not in column 5 , when the contrast is between $5^{\text {th }}$ and $7^{\text {th }}$ grade. It should also be noted that the clustered standard errors for blacks are much lower than the unadjusted standard errors, suggesting an especially poor asymptotic approximation in this sample. Since the unclustered standard errors may be biased downward, the fixed effects estimates for blacks are at best suggestive. ${ }^{17}$

\section{Instrumental Variables Estimates}

There are at least two reasons why the estimates in section III could be biased by omitted variables. First, school officials may reduce class size when students are doing poorly or allow larger classes when

\footnotetext{
${ }^{17}$ As with the cell means analog of the OLS estimates in Table 6, a grouped version of the fixed effects analysis, following cohorts instead of pupils and limited to pupils observed in the same school in $3^{\text {rd }}$ and $5^{\text {th }}$ or $5^{\text {th }}$ and $7^{\text {th }}$ grades who did not repeat a grade, generates estimates similar to those in Table 7. Standard errors for the grouped fixed effects estimates for blacks are slightly below the uncorrected (i.e., unclustered) standard errors in Table 7.
} 
students are doing well. ${ }^{18}$ This notion is supported by the fact that non-Metco students in smaller classes have lower average scores than those in larger classes. Since Metco students are more likely to be assigned to smaller classes, this can generate spurious negative correlation between percent Metco and non-Metco achievement. Although both the OLS and fixed-effects estimates in Tables 6 and 7 control for class size, linear control may be inadequate and class size may not be measured accurately. A second source of bias, and one that works in the opposite direction, may arise from efforts to place Metco students where nonMetco students are doing relatively well or performance is improving. Discussions with school officials suggest that Metco placement is not as systematic as this hypothetical assignment mechanism requires. In any case, the instrumental variables strategy provides a check on both sorts of bias.

\section{A. Maimonides at 25}

The IV estimates exploit the fact that Metco students are assigned to Brookline schools partly on the basis of a space constraint. Recall that class size in Brookline is contractually capped at 25 . Moreover, in practice, classes as large as 25 are rare. This motivates the following version of what Angrist and Lavy (1999) termed Maimonides' rule, after the biblical scholar Maimonides', who proposed a maximum class size of 40 . With a maximum size of 25 , the rule is:

$$
\mathrm{r}_{\mathrm{gjt}}=\mathrm{e}_{\mathrm{gjl}} /\left(\operatorname{int}\left(\mathrm{e}_{\mathrm{gjl}} / 25\right)+1\right)
$$

where $\mathrm{e}_{\mathrm{gjt}}$ is non-Metco enrollment and $\mathrm{r}_{\mathrm{gjt}}$ is predicted class size. Figure 1 plots $\mathrm{r}_{\mathrm{gjt}}$ against enrollment using a dotted line and actual class size against enrollment using connected dots, for $3^{\text {rd }}$ graders. The figure shows that $\mathrm{r}_{\mathrm{gjt}}$ captures the relation between $3^{\text {rd }}$ grade enrollment and class size remarkably well.

Our discussions with school officials suggest that Metco students are typically assigned to schools in light of information about enrollment anticipated for the coming year. When classes are expected to be

${ }^{18}$ For example, accelerated Math classes at one school are offered with the stipulation (spelled out in a memo to parents) that these classes are larger than usual. 
small, the Boston Metco office is notified that space is available for Metco students. We model the Metco assignment process as allocating 1 Metco student per classroom if predicted enrollment is less than 23 . We use predicted instead of actual class size to determine space availability since the latter may be endogenous and is unknown when Metco students are accepted. This reasoning leads to the following instrumental variable for the number of Metco students in a class:

$$
\mathrm{z}_{\mathrm{gjt}}=\min \left[\max \left(23-\mathrm{r}_{\mathrm{git}}, 0\right), 1\right]
$$

The first stage is plotted in Figure 2 for $3^{\text {rd }}$ graders, with enrollment again shown on the $\mathrm{X}$-axis.

Although much of the variation in the number of Metco students remains unexplained by this model, $\mathrm{Z}_{\mathrm{gjt}}$ is clearly correlated with Metco placements, at least in the $3^{\text {rd }}$ grade. The IV analysis that follows is limited to $3^{\text {rd }}$ graders since $\mathrm{z}_{\mathrm{gjt}}$ is most highly correlated with the number of Metco students entering the school system. The first-stage relation for $5^{\text {th }}$ and $7^{\text {th }}$ graders is weak, probably because most Metco students in higher grades are inherited from earlier grades, and because the predictive power of $r_{\mathrm{gjt}}$ for class size is weaker for $5^{\text {th }}$ and especially $7^{\text {th }}$ grades.

The second-stage equation for the IV estimates is:

$$
\mathrm{y}_{\mathrm{jti}}=\beta_{2 \mathrm{j}}+\gamma_{2 \mathrm{t}}+\delta_{2} a_{\mathrm{jt}}+\lambda_{2} n_{\mathrm{jt}}+\phi_{2} e_{\mathrm{jt}}+\mathrm{X}_{\mathrm{i}}^{\prime} \Gamma_{2}+\xi_{\mathrm{jti}},
$$

where $a_{\mathrm{jt}}$ is the average number of Metco students per classroom in grade $\mathrm{j}$ in year $\mathrm{t}, n_{\mathrm{jt}}$ is the corresponding number of non-Metco students, and $e_{\mathrm{jt}}$ is total grade enrollment. Note that this model differs from that used to construct the OLS estimates. Here, we replace $m_{\mathrm{gjj}}$, the percent Metco in a grade, with $a_{\mathrm{j}}$, the average number Metco in a class, while total class size, $s_{\mathrm{gj}}$, is replaced with non-Metco class size, $n_{\mathrm{jt}}$. Equation (6) is more attractive than equation (3) in this context because it allows us to experiment with alternative assumptions regarding non-Metco class size effects. In particular, it seems sensible to use (6) to explore specifications where $a_{\mathrm{jt}}$ is treated as endogenous while $n_{\mathrm{jt}}$ is not. In contrast, it is difficult to rationalize a model that treats the percent Metco, $m_{\mathrm{jt}}\left(=a_{\mathrm{jl}} / s_{\mathrm{gjt}}\right)$, as endogenous, while at the same time treating total class size, $s_{\mathrm{git}}\left(=a_{\mathrm{jt}}+n_{\mathrm{jt}}\right)$, as exogenous. 
In principal, two instruments, $\mathrm{z}_{\mathrm{gjt}}$ and $\mathrm{r}_{\mathrm{gjt}}$, are available for the two potentially endogenous variables, $a_{\mathrm{jt}}$ and $n_{\mathrm{jt}}$. In practice, however, both of these instruments are nonlinear functions of the same underlying grade-level enrollment variable, $e_{\mathrm{jt}}$ (Note that $\mathrm{z}_{\mathrm{gtt}}$ is approximately equal to a dummy variable for $\mathrm{r}_{\mathrm{gjt}}<23$ ). Consequently, two-stage least squares (2SLS) estimates treating class size as endogenous are imprecise. We therefore begin by discussing models where only the number of Metco students per class is treated as endogenous, while imposing alternative assumptions regarding the impact of non-Metco class size. The first set of estimates is from models that include non-Metco class size as an exogenous covariate. The second set is based on a model that restricts class size effects to be zero. Finally, we compute estimates assuming that $\lambda_{2}$ equals -.53, a value derived from the Angrist and Lavy (1999) class size study.

For purposes of comparison, the top panel of Table 8 reports OLS estimates of equation (6) for each score in the full sample of $3^{\text {rd }}$ graders. Similar to the regressions in Table 6 with percent Metco as an explanatory variable, these estimates show no relation between the number of Metco students in a class and non-Metco students' test scores. The table also reports positive and significant coefficients on non-Metco class size when this variable is treated as an exogenous covariate. The positive class size coefficients seem unlikely to have a causal interpretation, and probably reflect a tendency to group high achievers into larger classes. The OLS estimates of the effect of the number Metco remain small and insignificant regardless of whether the model includes non-Metco class size and non-Metco enrollment variables as controls.

\section{B. First Stage and Reduced-form Effects}

The first stage equation for models where non-Metco class size is treated as exogenous can be written

$$
a_{\mathrm{jt}, \mathrm{i}}=\beta_{1 \mathrm{j}}+\gamma_{1 \mathrm{t}}+\delta_{1} z_{\mathrm{jt}}+\lambda_{1} n_{\mathrm{jt}}+\phi_{1} e_{\mathrm{j}}+\mathrm{X}_{\mathrm{i}}{ }^{\prime} \Gamma_{1}+v_{\mathrm{jt}, \mathrm{i}}
$$

where $a_{\mathrm{jt}, \mathrm{i}}$ is the average number of Metco students per class in school $\mathrm{j}$ at date $\mathrm{t}$, and the $\mathrm{i}$ subscript indicates that the equation is estimated using micro data. The reduced-form effect of $z_{\mathrm{jt}}$ on test scores is 


$$
\pi=\delta_{1} \delta_{2}
$$

obtained by substituting equation (7) into equation (6). First-stage estimates for models where the effects of non-Metco class size are assumed to be 0 or -.53 were calculated by setting $\lambda_{1}=0$ in this equation, so that the model is identified using $\mathrm{z}_{\mathrm{jt}}$ as the sole instrument.

Panel B in Table 8 reports the first stage estimates for the sample with non-missing core NPR scores. The estimates of $\delta_{1}$, ranging from .87 to .92 , are largely insensitive to assumptions regarding the impact of non-Metco class size. The first-stage coefficients are precisely estimated with t-statistics of over 5 for each model. Because the first stage estimates are close to one, the reduced form effect, $\pi$, is almost the same as the second stage coefficient, $\delta_{2}$.

The corresponding reduced form estimates are reported in the bottom panel of Table 8 . Consistent with the OLS estimates reported in the top panel, estimates from models that treat non-Metco class size as exogenous show no relation between $z_{\mathrm{jt}}$ and test scores. The results become increasingly negative, however, as we move to models where the assumed class size effect is zero, and finally to models where the class size effect is set at -.53. In the latter specification, the estimated effect of Metco students on their non-Metco peers is negative and at least marginally significant for the core NPR score and for two of the three subject tests. For example, the estimate in column (3) suggests that the presence of a Metco student reduces average non-Metco scores by 2.7 points, with a clustered standard error of 1.6.

The strong positive OLS estimates of the effects of class size on achievement suggest an endogeneity problem with this variable. Discounting positive effects, however, it remains to chose between specifications where class size effects are zero and specifications where class size effects are substantially negative, as in Angrist and Lavy (1999). Because classes are much smaller and SES much higher in Brookline, zero may be a better estimate of the average causal effect in this context. In the next subsection, we discuss the results of 2SLS estimates using multiple instruments in an attempt to estimate the effects of number Metco and nonMetco class size jointly. 


\section{2SLS estimates}

As noted above, the instrumental variable $\mathrm{z}_{\mathrm{ggt}}$ is approximately equal to an indicator for $\mathrm{r}_{\mathrm{gjt}}<23$. Since predicted class size ranges from 16 to 24.67 in the $3^{\text {rd }}$ grade sample, it seems natural to look for increased statistical power by adding dummy instruments for values of $r_{\mathrm{gjt}}$ other than 23 . We therefore computed 2SLS estimates using an instrument set consisting of 6 indicator variables for high values of predicted class size:

$$
\left(19 \leq \mathrm{r}_{\mathrm{gjt}}<20\right),\left(20 \leq \mathrm{r}_{\mathrm{gjt}}<21\right),\left(21 \leq \mathrm{r}_{\mathrm{gjt}}<22\right),\left(22 \leq \mathrm{r}_{\mathrm{gjt}}<23\right),\left(23 \leq \mathrm{r}_{\mathrm{gjt}}<24\right) \text {, and }\left(24 \leq \mathrm{r}_{\mathrm{gjt}}<25\right) \text {; }
$$

plus a linear term for $r_{\mathrm{gjt}}$ itself. Both the number Metco and non-Metco class size were treated as endogenous.

The 2SLS estimates, reported in Table 9, support the notion that class size has no effect on nonMetco achievement in Brookline. The estimated class size coefficients are all much smaller than the corresponding OLS estimates in Table 8. Consistent with the fact that the estimated class size effects are close to zero, the estimated effects of Metco are similar with and without class size controls (see, e.g., columns 1-2 for core NPR scores). Some models add linear enrollment controls as an exogenous covariate.

Not surprisingly given the estimated non-Metco class size effects and the IV results in Table 8, the expanded instrument set generates coefficient estimates for the effect of Metco that are not significantly different from zero in the full sample. For example, the estimated effect of Metco on core NPR scores with or without class size controls is about -.80 , with a standard error of 1.35 . The estimate in column 3 , which reports the results of dropping enrollment controls from the model for NPR scores, is -1.36 with a standard error of 1.1, similar to the estimate in column 2 of Table 8, and slightly more precise. Note, however, that the 2SLS estimates are only about half as precise as corresponding the OLS estimates in Table 6. (To make the comparison, divide the standard errors in Table 6 by 20).

The 2SLS estimates for black students are reported in panel B of Table 9. These estimates are also broadly consistent with the OLS estimates reported in Table 6, suggesting Metco students have a negative 
impact on the reading and language scores of their $3^{\text {rd }}$ grade black peers. Like the OLS estimates, the 2SLS estimates show no effect on math scores. The estimated effects of percent Metco on reading scores without class size controls are significantly different from zero, while other estimates are not as sharp. Some of the 2SLS estimates for blacks are also markedly larger than the corresponding OLS estimates, perhaps implausibly so. On the other hand, the 2SLS estimates with controls for class size and enrollment are reasonably close to the OLS estimates in Table 6. The estimated class size effects are not significantly different from zero for blacks.

As a final check on the results, we re-estimated the OLS model separately for male and female students. Just as the number of Metco students seem more likely to affect minority residents of Brookline than whites, the fact that Metco students are disproportionately female suggests it is worth looking for differential effects by sex. We return to OLS for this analysis since the IV and OLS estimates are broadly consistent, while the OLS estimates are more precise. The additional OLS results, reported in Tables 10a for boys and 10b for girls, support the notion that within-gender effects are more important. The only significant estimates in the two tables are for black girls in $3^{\text {rd }}$ grade. The estimates are significant for effects on language and reading scores, but not math.

\section{Summary and Conclusions}

Although Metco students have much lower test scores than students in the host district, we find little evidence of socially or statistically significant effects of Metco students on their non-Metco classmates. Both OLS and IV estimates show no effect of Metco students in the full sample of non-Metco students. The standard errors for the OLS estimate are such that we can rule out pure test-score-mediated peer effects at the high end of those reported in the literature, though the results are consistent with smaller effects. In contrast with most of the findings in previous research on peer effects, our results also suggest there is no adverse impact of increasing the percent minority on most students. 
On the other hand, consistent with previous research, which shows racial composition effects to be strongest within racial groups, we find some evidence for a negative impact of percent Metco on the reading and language scores of minority $3^{\text {rd }}$ graders, especially blacks. These results turn out to be driven by effects on $3^{\text {rd }}$ grade girls, consistent with the fact that Metco students are more likely to be female. A possible explanation for this result is that Metco students displace relatively high-scoring local students who interact with young black girls who live in the host district. But many of these estimates are imprecise. Moreover, the highly localized nature of this finding, and the fact that it does not appear in higher grades, lead us to conclude that any effects of the Metco program on minority students in the host district are modest and shortlived.

In conclusion, it bears emphasizing that our analysis of Metco is limited to a narrow study of test scores as measured by achievement on the ITBS. These results should be weighed against any possible effects of Metco on racial attitudes in Boston and host districts, and any benefits for Metco participants. For example, our results suggest that Metco students benefit from their time in the Brookline system since their relative achievement improves as grade advances. In future work, we hope to look at the impact on Metco pupils more systematically, as well as other aspects of this unique and historically significant program. 


\section{REFERENCES}

Angrist, Joshua D., and Victor Lavy (1999), “Using Maimonides' Rule to Estimate the Effect of Class Size on Student Achievement," Quarterly Journal of Economics, May 1999.

Armor, David (1972), "The Evidence on Busing," The Public Interest 28, 90-126.

Batson, Ruth M. and Hayden, Robert C., A History of Metco, The Metropolitan Council for Educational Opportunity: A Suburban Education for Boston's Urban Students, Boston, MA: Select Publications, 1987.

Bertrand, Marianne, Erzo Luttmer, and Sendhil Mullainathan (2000), "Network Effects and Welfare Cultures," The Quarterly Journal of Economics, August.

Bethel, Alison (1999), “black Children from Well-Off Families Face Dueling Identities,” Boston Globe, September 19, Page C1.

Boardman, Richard, and Linda Brandt (1968), Metco-A Descriptive Report (ERIC No: ED088225).

Boozer, Michael A., Alan B. Krueger, and Shari Wolkon (1992), "Race and School Quality Since Brown v. Board of Education," Brookings Papers on Economic Activity: Microeconomics, 269-326.

Case, Anne, and Lawrence Katz (1991), "The Company You Keep: The Effects of Family and Neighborhood on Disadvantaged Youth,” NBER Working Paper 3705, May.

Cohen Muriel (1990), “After 25 years, Lincoln Takes a Hard Look at Metco,” Boston Globe, June 9, p. 21.

Coleman, James S. (1975), “Trends in School Segregation: 1968-73," Urban Institute Paper No. 722-03-01, Washington, DC: August.

Clarke, Keith W. (1975), A Descriptive Study of the Metco Program, Boston University School of Education, D. Ed. thesis, July (ERIC No: ED124631).

Clotfelter, Charles (1999), “Are whites Still 'Fleeing'? Racial Patterns and Enrollment Shifts in Urban Public Schools, 1987-1996,” NBER Working Paper No. 7290, August.

Crain, Robert L., and Jack Strauss (1985), "School Desegregation and black occupational Attainment: Results from a Long-Term Experiment," working paper, Center for Social Organization of Schools, Johns Hopkins University, Baltimore.

Donald, Stephen, and Kevin Lang (2001), "Inference with Differences-in-Differences and Other Panel Data," Boston University Department of Economics, mimeo, March.

Eaton, Susan E., The Other Boston Busing Story. New Haven, CT: Yale University Press, March 2001.

Elliott, Cary A. (1998), "Get on the Bus? The Long Run Effect of Metco Suburban Education on Inner-City Students," Chapter II in Three Essays in Applied Microeconomics, Princeton University Economics Department, Ph.D. thesis, November.

Evans, William N., Wallace E. Oates, and Robert M. Schwab (1992), "Measuring Peer Effects: A Study of Teenage Behavior," Journal of Political Economy 100, 966-991.

Feng, Ziding, P. Diehr, A. Peterson, and D. McLerran (2001), "Selected Statistucal issues in Group Randomized Trials," Annual Review of Public Health 22, 167-87.

Guryan, Jonathan (2001), "Desegregation and black Dropout Rates,” NBER Working Paper 8345, June.

Hanushek, Eric, J.F. Kain, and S.G. Rivkin (2002), "New Evidence About Brown v. Board of Education: The Complex Effects of School Racial Composition on Achievement,"NBER Working Paper 8741, January.

Hoxby, Caroline (2000), "Peer Effects in the Classroom: Learning from Gender and Race Variation," NBER Working Paper 7867, August.

Jaggia, Sanjay, and David G. Tuerck (2000), Promoting Good Schools Through Wise Spending, Boston: The Beacon Hill Institute at Suffolk University.

Katz, Lawrence F., Jeffrey R. Kling, and Jeffrey B. Leibman (2001), "Moving to Opportunity in Boston: Early Results of a Randomized Mobility Experiment," Quarterly Journal of Economics 116, 607-654. 
Lazear, Edward P. (2001), “Educational Production," Quarterly Journal of Economics 116, 777-803.

Liang, Kung-yee, and Scott L. Zeger (1986), "Longitudinal Data Analysis Using Gerealized Linear Models," Biometrika 73, 13-22.

Metropolitan Council for Educational Opportunity, Report of the Executive Director (Interim Report), Boston, MA, October 19, 1970. , Annual Report, 1985-86, Boston, MA 1986.

Orfield, Gary, et al (1997), "City-Suburban Desegregation: Parent and Student Perspectives in Metropolitan Boston," working paper, The Civil Rights Project: Harvard University.

Rivkin, Steven G. (2000), "School Desegregation, Aacdemic Attainment, and Earnings," Journal of Human Resources 35 (Spring), 333-346.

Rossell, Christine, and David Armor (1996), "The Effectiveness of School Desegregation Plans, 1968-1991," American Politics Quarterly 24, 267-302.

Rouse, Cecilia E. (1998), "Private School Vouchers and Student Achievement: An Evaluation of the Milwaukee Parental Choice Program," Quarterly Journal of Economics, 113 (May 1998), 553-602.

Smith, James P., and Finis Welch (1989), "black Economic Progress After Myrdal," Journal of Economic Literature XXVII, 519-64.

Tye, Larry (1995a), "High Hopes, Hard Questions: Metco Faces Scrutiny in Era of Education Change," Boston Globe, December 3, Metro Section, page 1.

Tye, Larry (1995b), Metco has Opened up New World," Boston Globe, December 4, Metro Section, p. 1.

Vigue, Doreen Iudica (1999), "Metco Students May be Ousted from Lynnfield," Boston Globe, March 2, page A1.

Welch, Finis, and Audrey Light (1987), "New Evidence on School Desegregation," US Commission on Civil Rights Clearinghouse Publication 92, June. 


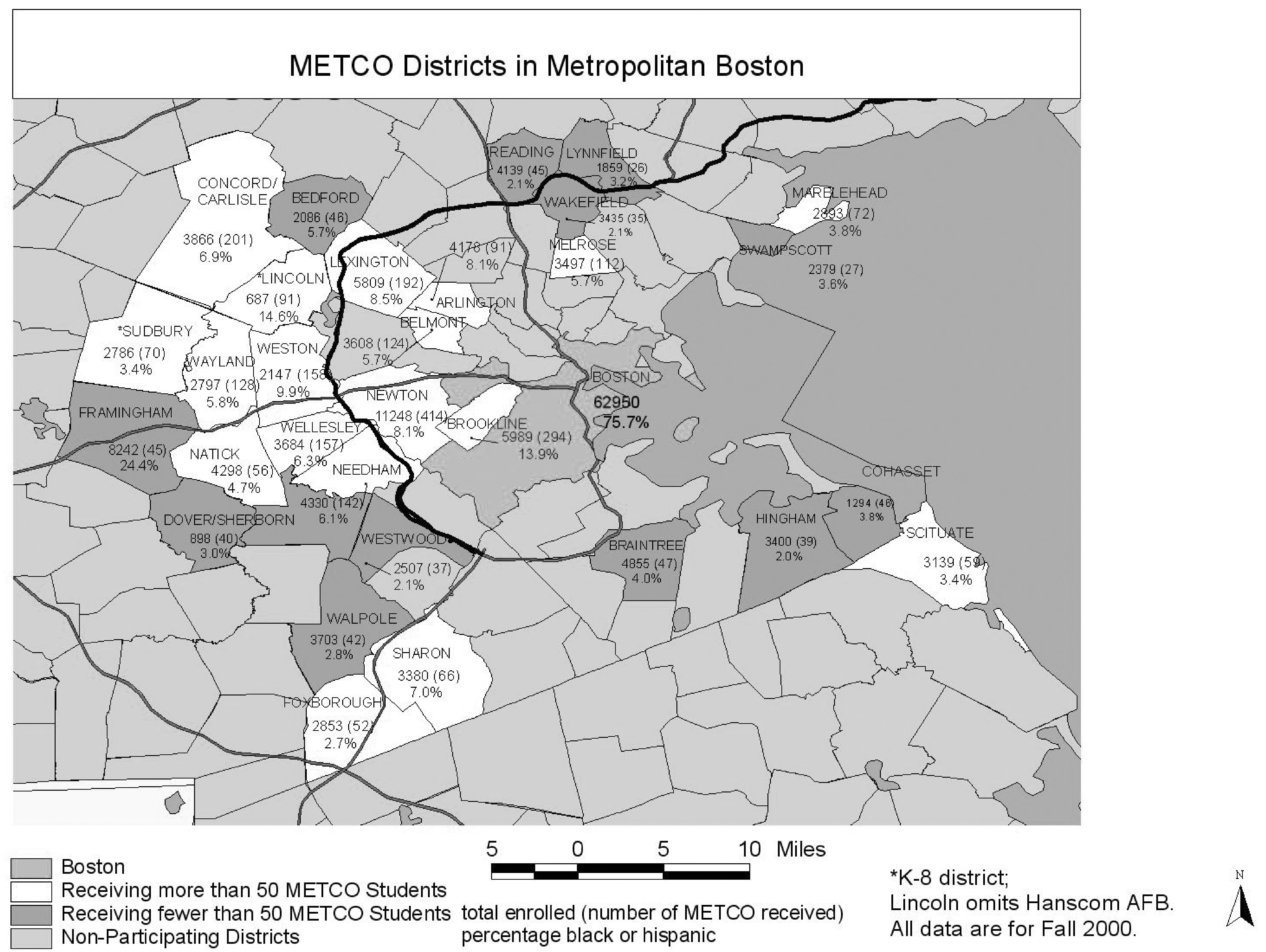


Table 1

Summary Statistics

\begin{tabular}{|c|c|c|c|c|c|c|c|c|c|c|c|c|c|c|c|c|}
\hline \multirow[b]{2}{*}{ Grade } & \multirow[b]{2}{*}{ School Yeat } & \multicolumn{2}{|c|}{$\begin{array}{c}\text { School } \\
\text { Characteristics } \\
\end{array}$} & \multicolumn{6}{|c|}{$\begin{array}{c}\text { All } \\
\text { Pupils }\end{array}$} & \multicolumn{3}{|c|}{$\begin{array}{l}\text { Tested } \\
\text { Pupils }\end{array}$} & \multicolumn{4}{|c|}{$\begin{array}{c}\text { Metco Tested } \\
\text { Pupils } \\
\end{array}$} \\
\hline & & $\begin{array}{c}\text { classes } \\
\text { (1) }\end{array}$ & $\begin{array}{l}\text { class size } \\
\text { (2) }\end{array}$ & $\begin{array}{l}\text { Enrolled } \\
\text { (3) }\end{array}$ & $\begin{array}{l}\text { Metco } \\
\text { (4) }\end{array}$ & $\begin{array}{c}\text { \% Metco } \\
\text { (5) }\end{array}$ & $\begin{array}{c}\% \mathrm{ESL} / \mathrm{TBE} \\
(6)\end{array}$ & $\begin{array}{c}\text { \% Sp. Ed. } \\
\text { (7) }\end{array}$ & $\begin{array}{c}\text { \% Tested } \\
\text { (8) }\end{array}$ & $\begin{array}{c}\% \text { Metco } \\
\text { (9) }\end{array}$ & $\begin{array}{c}\text { \% Black } \\
(10)\end{array}$ & $\begin{array}{l}\text { \% Sp. Ed. } \\
\text { (11) }\end{array}$ & $\begin{array}{c}\text { \% Black } \\
\text { (12) }\end{array}$ & $\begin{array}{c}\text { \% Asian } \\
\text { (13) }\end{array}$ & $\begin{array}{c}\text { \% Hispanic } \\
\text { (14) }\end{array}$ & $\begin{array}{c}\text { \% Male } \\
\text { (15) }\end{array}$ \\
\hline \multirow[t]{7}{*}{3} & 1994 & 24 & 20.8 & 498 & 16 & 3.21 & 9.24 & - & 88.2 & 3.64 & 9.79 & 14.12 & 81.3 & 6.25 & 6.25 & 25.0 \\
\hline & 1995 & 24 & 20.7 & 496 & 13 & 2.62 & 9.07 & - & 86.5 & 3.03 & 8.16 & 14.45 & 84.6 & 0.00 & 15.38 & 38.5 \\
\hline & 1996 & 23 & 22.2 & 511 & 20 & 3.91 & 11.94 & 18.79 & 81.2 & 4.34 & 9.64 & 15.42 & 88.9 & 0.00 & 5.56 & 38.9 \\
\hline & 1997 & 24 & 20.4 & 490 & 25 & 5.10 & 11.43 & 21.22 & 85.3 & 4.78 & 11.48 & 16.99 & 85.0 & 15.00 & 0.00 & 50.0 \\
\hline & 1998 & 23 & 21.9 & 503 & 34 & 6.76 & 9.94 & 21.27 & 87.9 & 7.24 & 14.03 & 21.27 & 90.6 & 3.13 & 6.25 & 37.5 \\
\hline & 1999 & 22 & 20.6 & 454 & 16 & 3.52 & 11.45 & 18.50 & 87.9 & 3.76 & 6.77 & 18.05 & 66.7 & 13.33 & 13.33 & 33.3 \\
\hline & 2000 & 24 & 18.8 & 451 & 19 & 4.21 & 11.09 & 18.18 & 88.9 & 4.24 & 10.97 & 16.46 & 100.0 & 0.00 & 0.00 & 35.3 \\
\hline \multirow[t]{7}{*}{5} & 1994 & 24 & 21.1 & 506 & 27 & 5.34 & 9.29 & - & 89.1 & 5.99 & 11.53 & 10.86 & 88.9 & 3.70 & 0.00 & 51.9 \\
\hline & 1995 & 23 & 20.3 & 467 & 27 & 5.78 & 9.42 & - & 79.0 & 7.32 & 11.38 & 15.45 & 85.2 & 0.00 & 3.70 & 40.7 \\
\hline & 1996 & 24 & 20.1 & 483 & 24 & 4.97 & 6.63 & 19.05 & 88.0 & 4.94 & 12.00 & 14.12 & 85.7 & 4.76 & 4.76 & 33.3 \\
\hline & 1997 & 22 & 22.8 & 501 & 18 & 3.59 & 6.39 & 19.76 & 91.4 & 3.06 & 7.64 & 16.59 & 85.7 & 0.00 & 14.29 & 35.7 \\
\hline & 1998 & 23 & 21.2 & 487 & 27 & 5.54 & 6.57 & 21.77 & 90.3 & 6.14 & 12.27 & 19.32 & 85.2 & 0.00 & 7.41 & 40.7 \\
\hline & 1999 & 24 & 20.5 & 493 & 25 & 5.07 & 7.91 & 20.08 & 89.2 & 5.45 & 10.45 & 17.95 & 83.3 & 16.67 & 0.00 & 50.0 \\
\hline & 2000 & 23 & 20.4 & 470 & 34 & 7.23 & 7.87 & 20.43 & 90.9 & 7.49 & 13.35 & 20.14 & 87.5 & 3.13 & 6.25 & 31.3 \\
\hline \multirow[t]{7}{*}{7} & 1994 & 19 & 21.9 & 417 & 25 & 6.00 & 6.95 & - & 89.4 & 6.70 & 13.14 & 13.40 & 88.0 & 4.00 & 0.00 & 52.0 \\
\hline & 1995 & 23 & 19.9 & 457 & 24 & 5.25 & 7.00 & - & 87.3 & 6.02 & 11.28 & 16.54 & 79.2 & 4.17 & 12.50 & 37.5 \\
\hline & 1996 & 23 & 20.8 & 479 & 30 & 6.26 & 8.35 & 13.78 & 89.4 & 6.54 & 10.51 & 12.62 & 82.1 & 3.57 & 3.57 & 53.6 \\
\hline & 1997 & 21 & 20.0 & 420 & 31 & 7.38 & 6.19 & 24.52 & 93.1 & 7.42 & 12.28 & 20.46 & 69.0 & 13.79 & 10.34 & 41.4 \\
\hline & 1998 & 23 & 20.0 & 460 & 28 & 6.09 & 3.91 & 20.43 & 94.6 & 6.21 & 11.95 & 18.16 & 88.9 & 3.70 & 3.70 & 44.4 \\
\hline & 1999 & 23 & 20.6 & 473 & 20 & 4.23 & 6.13 & 19.87 & 93.7 & 4.29 & 9.26 & 17.83 & 94.7 & 0.00 & 5.26 & 36.8 \\
\hline & 2000 & 23 & 19.9 & 457 & 26 & 5.69 & 7.44 & 22.54 & 92.8 & 6.13 & 12.74 & 21.46 & 84.6 & 0.00 & 11.54 & 38.5 \\
\hline
\end{tabular}

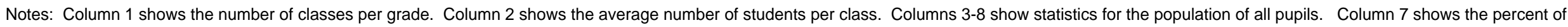

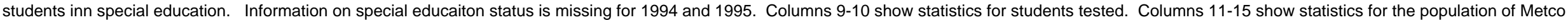

students tested. Tests were adminstered in March in the 1994 and 1995 school years and in November in other years. 
Table 2

Distribution of Percent Metco by School

\begin{tabular}{|c|c|c|c|c|c|c|c|c|c|}
\hline Grade & School Year & (1) & (2) & (3) & (4) & (5) & (6) & (7) & (8) \\
\hline \multirow[t]{7}{*}{3} & 1994 & $\begin{array}{c}0.0 \\
(0,1)\end{array}$ & $\begin{array}{c}0.0 \\
(0,2)\end{array}$ & $\begin{array}{c}2.2 \\
(1,3)\end{array}$ & $\begin{array}{c}3.8 \\
(3,4)\end{array}$ & $\begin{array}{c}3.9 \\
(3,5)\end{array}$ & $\begin{array}{c}4.7 \\
(3,6)\end{array}$ & $\begin{array}{c}5.6 \\
(3,7)\end{array}$ & $\begin{array}{c}6.0 \\
(4,8)\end{array}$ \\
\hline & 1995 & $\begin{array}{c}0.0 \\
(0,3)\end{array}$ & $\begin{array}{c}0.0 \\
(0,6)\end{array}$ & $\begin{array}{c}1.4 \\
(1,1)\end{array}$ & $\begin{array}{c}2.0 \\
(1,7)\end{array}$ & $\begin{array}{c}2.3 \\
(1,2)\end{array}$ & $\begin{array}{c}3.0 \\
(2,5)\end{array}$ & $\begin{array}{c}3.5 \\
(3,4)\end{array}$ & $\begin{array}{c}8.1 \\
(5,8)\end{array}$ \\
\hline & 1996 & $\begin{array}{c}0.0 \\
(0,2)\end{array}$ & $\begin{array}{c}1.4 \\
(1,5)\end{array}$ & $\begin{array}{c}1.6 \\
(1,7)\end{array}$ & $\begin{array}{c}2.2 \\
(1,8)\end{array}$ & $\begin{array}{c}3.3 \\
(3,4)\end{array}$ & $\begin{array}{c}5.8 \\
(4,6)\end{array}$ & $\begin{array}{c}6.0 \\
(5,1)\end{array}$ & $\begin{array}{l}11.6 \\
(5,3)\end{array}$ \\
\hline & 1997 & $\begin{array}{c}1.2 \\
(1,5)\end{array}$ & $\begin{array}{c}1.4 \\
(1,4)\end{array}$ & $\begin{array}{c}2.8 \\
(2,1)\end{array}$ & $\begin{array}{c}3.4 \\
(2,7)\end{array}$ & $\begin{array}{c}5.3 \\
(3,6)\end{array}$ & $\begin{array}{c}7.0 \\
(3,2)\end{array}$ & $\begin{array}{l}11.1 \\
(5,3)\end{array}$ & $\begin{array}{l}12.7 \\
(8,8)\end{array}$ \\
\hline & 1998 & $\begin{array}{c}1.7 \\
(1,5)\end{array}$ & $\begin{array}{c}1.8 \\
(1,6)\end{array}$ & $\begin{array}{c}4.5 \\
(2,2)\end{array}$ & $\begin{array}{c}6.1 \\
(3,8)\end{array}$ & $\begin{array}{c}6.3 \\
(3,3)\end{array}$ & $\begin{array}{c}7.4 \\
(5,7)\end{array}$ & $\begin{array}{c}9.3 \\
(8,4)\end{array}$ & $\begin{array}{c}12.0 \\
(11,1)\end{array}$ \\
\hline & 1999 & $\begin{array}{c}0.0 \\
(0,6)\end{array}$ & $\begin{array}{c}0.0 \\
(0,8)\end{array}$ & $\begin{array}{c}0.0 \\
(0,3)\end{array}$ & $\begin{array}{c}2.3 \\
(1,7)\end{array}$ & $\begin{array}{c}4.4 \\
(4,4)\end{array}$ & $\begin{array}{c}4.5 \\
(2,2)\end{array}$ & $\begin{array}{c}4.9 \\
(3,5)\end{array}$ & $\begin{array}{c}9.5 \\
(6,1)\end{array}$ \\
\hline & 2000 & $\begin{array}{c}0.0 \\
(0,7)\end{array}$ & $\begin{array}{c}0.0 \\
(0,1)\end{array}$ & $\begin{array}{c}1.3 \\
(1,4)\end{array}$ & $\begin{array}{c}1.7 \\
(1,6)\end{array}$ & $\begin{array}{c}5.8 \\
(4,5)\end{array}$ & $\begin{array}{c}6.1 \\
(3,2)\end{array}$ & $\begin{array}{c}7.7 \\
(3,3)\end{array}$ & $\begin{array}{l}18.4 \\
(7,8)\end{array}$ \\
\hline \multirow[t]{7}{*}{5} & 1994 & $\begin{array}{c}1.5 \\
(1,6)\end{array}$ & $\begin{array}{c}1.5 \\
(1,1)\end{array}$ & $\begin{array}{c}3.7 \\
(2,7)\end{array}$ & $\begin{array}{c}4.3 \\
(3,5)\end{array}$ & $\begin{array}{c}6.6 \\
(4,2)\end{array}$ & $\begin{array}{c}7.0 \\
(4,8)\end{array}$ & $\begin{array}{c}8.9 \\
(7,4)\end{array}$ & $\begin{array}{c}9.6 \\
(5,3)\end{array}$ \\
\hline & 1995 & $\begin{array}{c}2.4 \\
(2,4)\end{array}$ & $\begin{array}{c}2.6 \\
(2,1)\end{array}$ & $\begin{array}{c}2.9 \\
(2,5)\end{array}$ & $\begin{array}{c}3.8 \\
(2,2)\end{array}$ & $\begin{array}{c}7.0 \\
(3,8)\end{array}$ & $\begin{array}{c}8.9 \\
(4,7)\end{array}$ & $\begin{array}{c}9.5 \\
(4,3)\end{array}$ & $\begin{array}{l}14.3 \\
(8,6)\end{array}$ \\
\hline & 1996 & $\begin{array}{c}0.0 \\
(0,2)\end{array}$ & $\begin{array}{c}0.0 \\
(0,1)\end{array}$ & $\begin{array}{c}2.7 \\
(2,5)\end{array}$ & $\begin{array}{c}4.5 \\
(3,8)\end{array}$ & $\begin{array}{c}4.9 \\
(4,4)\end{array}$ & $\begin{array}{c}7.1 \\
(4,7)\end{array}$ & $\begin{array}{c}9.1 \\
(5,6)\end{array}$ & $\begin{array}{l}14.0 \\
(6,3)\end{array}$ \\
\hline & 1997 & $\begin{array}{c}0.0 \\
(0,3)\end{array}$ & $\begin{array}{c}1.4 \\
(1,1)\end{array}$ & $\begin{array}{c}1.5 \\
(1,6)\end{array}$ & $\begin{array}{c}2.0 \\
(1,7)\end{array}$ & $\begin{array}{c}2.8 \\
(2,5)\end{array}$ & $\begin{array}{c}3.9 \\
(2,2)\end{array}$ & $\begin{array}{c}5.9 \\
(5,4)\end{array}$ & $\begin{array}{l}10.0 \\
(6,8)\end{array}$ \\
\hline & 1998 & $\begin{array}{c}0.0 \\
(0,2)\end{array}$ & $\begin{array}{c}1.6 \\
(1,5)\end{array}$ & $\begin{array}{c}1.8 \\
(1,7)\end{array}$ & $\begin{array}{c}2.4 \\
(1,8)\end{array}$ & $\begin{array}{c}3.3 \\
(3,4)\end{array}$ & $\begin{array}{c}9.1 \\
(6,6)\end{array}$ & $\begin{array}{l}10.2 \\
(5,3)\end{array}$ & $\begin{array}{c}12.7 \\
(10,1)\end{array}$ \\
\hline & 1999 & $\begin{array}{c}1.2 \\
(1,5)\end{array}$ & $\begin{array}{c}1.6 \\
(1,6)\end{array}$ & $\begin{array}{c}2.7 \\
(2,4)\end{array}$ & $\begin{array}{c}3.6 \\
(2,7)\end{array}$ & $\begin{array}{c}4.2 \\
(3,1)\end{array}$ & $\begin{array}{c}6.0 \\
(3,2)\end{array}$ & $\begin{array}{l}12.2 \\
(5,3)\end{array}$ & $\begin{array}{l}14.0 \\
(8,8)\end{array}$ \\
\hline & 2000 & $\begin{array}{c}2.0 \\
(1,6)\end{array}$ & $\begin{array}{c}3.4 \\
(2,5)\end{array}$ & $\begin{array}{c}6.7 \\
(3,2)\end{array}$ & $\begin{array}{c}7.3 \\
(3,3)\end{array}$ & $\begin{array}{c}7.7 \\
(5,7)\end{array}$ & $\begin{array}{c}7.7 \\
(6,4)\end{array}$ & $\begin{array}{c}9.3 \\
(8,1)\end{array}$ & $\begin{array}{l}12.5 \\
(6,8)\end{array}$ \\
\hline \multirow[t]{7}{*}{7} & 1994 & $\begin{array}{c}0.0 \\
(0,6)\end{array}$ & $\begin{array}{c}0.0 \\
(0,4)\end{array}$ & $\begin{array}{c}2.2 \\
(1,3)\end{array}$ & $\begin{array}{c}6.1 \\
(3,7)\end{array}$ & $\begin{array}{c}6.3 \\
(3,2)\end{array}$ & $\begin{array}{l}11.1 \\
(5,1)\end{array}$ & $\begin{array}{l}11.5 \\
(7,5)\end{array}$ & $\begin{array}{l}12.3 \\
(7,8)\end{array}$ \\
\hline & 1995 & $\begin{array}{c}1.7 \\
(1,1)\end{array}$ & $\begin{array}{c}2.5 \\
(2,4)\end{array}$ & $\begin{array}{c}3.5 \\
(2,8)\end{array}$ & $\begin{array}{c}4.7 \\
(2,2)\end{array}$ & $\begin{array}{c}6.3 \\
(4,5)\end{array}$ & $\begin{array}{c}6.5 \\
(4,6)\end{array}$ & $\begin{array}{c}8.5 \\
(4,3)\end{array}$ & $\begin{array}{l}10.4 \\
(5,7)\end{array}$ \\
\hline & 1996 & $\begin{array}{c}1.7 \\
(1,6)\end{array}$ & $\begin{array}{c}4.0 \\
(2,7)\end{array}$ & $\begin{array}{c}4.5 \\
(3,5)\end{array}$ & $\begin{array}{c}5.3 \\
(3,1)\end{array}$ & $\begin{array}{c}5.4 \\
(3,8)\end{array}$ & $\begin{array}{c}8.9 \\
(7,4)\end{array}$ & $\begin{array}{l}10.4 \\
(7,2)\end{array}$ & $\begin{array}{l}11.1 \\
(5,3)\end{array}$ \\
\hline & 1997 & $\begin{array}{c}2.6 \\
(2,4)\end{array}$ & $\begin{array}{c}3.9 \\
(2,2)\end{array}$ & $\begin{array}{c}4.6 \\
(3,1)\end{array}$ & $\begin{array}{c}4.8 \\
(3,5)\end{array}$ & $\begin{array}{c}7.5 \\
(3,7)\end{array}$ & $\begin{array}{c}7.7 \\
(3,8)\end{array}$ & $\begin{array}{l}16.2 \\
(6,3)\end{array}$ & $\begin{array}{l}19.1 \\
(9,6)\end{array}$ \\
\hline & 1998 & $\begin{array}{c}0.0 \\
(0,2)\end{array}$ & $\begin{array}{c}0.0 \\
(0,1)\end{array}$ & $\begin{array}{c}4.0 \\
(3,5)\end{array}$ & $\begin{array}{c}5.0 \\
(3,8)\end{array}$ & $\begin{array}{c}5.3 \\
(4,4)\end{array}$ & $\begin{array}{c}7.1 \\
(3,3)\end{array}$ & $\begin{array}{c}9.8 \\
(5,7)\end{array}$ & $\begin{array}{c}21.3 \\
(10,6)\end{array}$ \\
\hline & 1999 & $\begin{array}{c}1.7 \\
(1,6)\end{array}$ & $\begin{array}{c}2.0 \\
(1,7)\end{array}$ & $\begin{array}{c}2.0 \\
(1,2)\end{array}$ & $\begin{array}{c}2.3 \\
(1,3)\end{array}$ & $\begin{array}{c}2.8 \\
(2,1)\end{array}$ & $\begin{array}{c}3.0 \\
(2,5)\end{array}$ & $\begin{array}{c}6.0 \\
(5,4)\end{array}$ & $\begin{array}{l}14.0 \\
(7,8)\end{array}$ \\
\hline & 2000 & $\begin{array}{c}0.0 \\
(0,2) \\
\end{array}$ & $\begin{array}{c}1.4 \\
(1,5) \\
\end{array}$ & $\begin{array}{r}2.0 \\
(1,7) \\
\end{array}$ & $\begin{array}{c}2.2 \\
(2,4) \\
\end{array}$ & $\begin{array}{r}2.8 \\
(1,8) \\
\end{array}$ & $\begin{array}{r}10.0 \\
(5,6) \\
\end{array}$ & $\begin{array}{r}12.5 \\
(5,3) \\
\end{array}$ & $\begin{array}{c}14.9 \\
(11,1) \\
\end{array}$ \\
\hline
\end{tabular}

Notes: The table shows percent Metco in the 8 Brookline elementary schools, ordered from lowest to highest by date and grade. The first number in parentheses is the number of Metco pupils and the second is the rank for percent Metco in grade 3, 1994. 
Table 3: Test Scores

\begin{tabular}{|c|c|c|c|c|c|c|c|c|c|}
\hline \multirow[b]{2}{*}{ Grade } & \multirow[b]{2}{*}{ Subject } & \multicolumn{5}{|c|}{ Non-Metco Students } & \multicolumn{3}{|c|}{ Metco Students } \\
\hline & & $\begin{array}{l}\text { All } \\
(1)\end{array}$ & $\begin{array}{c}\text { Black } \\
(2) \\
\end{array}$ & $\begin{array}{c}\text { Hispanic } \\
(4)\end{array}$ & $\begin{array}{c}\text { Asian } \\
(3) \\
\end{array}$ & $\begin{array}{c}\text { White } \\
(5)\end{array}$ & $\begin{array}{l}\text { All } \\
(6)\end{array}$ & $\begin{array}{c}\text { Black } \\
(8)\end{array}$ & $\begin{array}{c}\text { Non-Black } \\
(9) \\
\end{array}$ \\
\hline \multirow[t]{12}{*}{3} & Core & 71.6 & 51.2 & 54.2 & 71.9 & 74.3 & 49.0 & 47.2 & 60.1 \\
\hline & & (24.2) & $(27.6)$ & (27.6) & (22.8) & (22.7) & (25.5) & (25.1) & (25.2) \\
\hline & & {$[6.8]$} & & & & & [22.2] & & \\
\hline & Reading & 70.7 & 51.7 & 54.9 & 63.7 & 74.8 & 47.9 & 46.1 & 58.8 \\
\hline & & $(24.7)$ & (28.4) & (26.4) & (23.8) & (22.8) & $(26.8)$ & $(26.8)$ & $(24.8)$ \\
\hline & & {$[5.9]$} & & & & & [21.4] & & \\
\hline & Math & 72.0 & 50.8 & 54.9 & 76.4 & 74.0 & 47.9 & 45.7 & 62 \\
\hline & & (24.7) & (28.4) & $(28.0)$ & (22.6) & (23.3) & $(26.4)$ & (26.3) & (23.4) \\
\hline & & [7.3] & & & & & [22.9] & & \\
\hline & Language & 67.8 & 49.9 & 52.9 & 71.6 & 69.5 & 52.9 & 51.6 & 60.8 \\
\hline & & (25.7) & $(27.4)$ & (28.5) & (23.7) & $(24.8)$ & (25.9) & $(25.6)$ & $(27.2)$ \\
\hline & & {$[7.1]$} & & & & & [21.2] & & \\
\hline \multirow[t]{12}{*}{5} & Core & 72.3 & 49.8 & 56.9 & 72.2 & 75.0 & 50.6 & 48.0 & 67.3 \\
\hline & & (22.7) & $(25.7)$ & (26.3) & (21.8) & (20.9) & (22.1) & (20.9) & (22.8) \\
\hline & & {$[5.1]$} & & & & & [15.8] & & \\
\hline & Reading & 72.4 & 52.2 & 57.9 & 65.2 & 76.3 & 52.5 & 49.9 & 68.9 \\
\hline & & (22.7) & (25.9) & (25.8) & (23.4) & (20.3) & (23.6) & (22.8) & (21.9) \\
\hline & & {$[4.3]$} & & & & & [16.9] & & \\
\hline & Math & 70.6 & 47.8 & 57.2 & 76.0 & 72.3 & 46.7 & 44.4 & 61.6 \\
\hline & & (23.2) & (25.3) & (26.8) & (21.3) & (21.8) & (26.4) & (22.3) & (24.3) \\
\hline & & [6.1] & & & & & [18.3] & & \\
\hline & Language & 69.2 & 49.2 & 54.8 & 70.1 & 71.5 & 52.9 & 50.5 & 67.8 \\
\hline & & (24.4) & (27.3) & (28.2) & (23.3) & (23.0) & (23.4) & (22.4) & (24.4) \\
\hline & & {$[6.1]$} & & & & & [16.6] & & \\
\hline \multirow[t]{12}{*}{7} & Core & 76.4 & 55.0 & 59.6 & 76.4 & 79.5 & 57.1 & 55.1 & 66.5 \\
\hline & & (21.8) & (24.4) & (27.9) & (19.8) & (19.8) & (20.7) & (20.2) & (20.5) \\
\hline & & [4.7] & & & & & [15.7] & & \\
\hline & Reading & 77.0 & 57.4 & 63.8 & 70.7 & 80.8 & 57.5 & 55.6 & 66.4 \\
\hline & & (22.6) & (25.3) & (27.5) & (23.5) & (20.2) & (22.6) & (22.5) & (21.2) \\
\hline & & [4.4] & & & & & [15.9] & & \\
\hline & Math & 74.0 & 51.4 & 55.4 & 78.7 & 76.4 & 55.9 & 54.5 & 63.3 \\
\hline & & (23.4) & (25.7) & (29.0) & (20.2) & (21.5) & (22.2) & (22.0) & (20.2) \\
\hline & & {$[5.0]$} & & & & & [17.1] & & \\
\hline & Language & 73.9 & 55.0 & 59.0 & 75.0 & 76.5 & 57.1 & 55.1 & 66.8 \\
\hline & & (22.4) & $(24.6)$ & (27.9) & (19.9) & (21.1) & (21.8) & (21.3) & (20.9) \\
\hline & & [5.3] & & & & & [17.5] & & \\
\hline
\end{tabular}

Notes: Reported test scores are means of the National Percentile Rank from the lowa Test of Basic Skills administered from the 1994-1995 school year through the 2000-2001 school year. Standard deviations are reported in parentheses. Standard deviations for the year, school, and grade cell means are in brackets in columns 1 and 6 . 
Table 4: The Effect of Metco on Average Test Scores

\begin{tabular}{|c|c|c|c|c|c|c|c|c|c|c|c|c|}
\hline \multirow[b]{3}{*}{ Subject } & \multicolumn{4}{|c|}{ Unweighted Means } & \multicolumn{4}{|c|}{ Weighted Means } & \multicolumn{4}{|c|}{ Peer Means } \\
\hline & (1) & (2) & (3) & (4) & (5) & (6) & (7) & (8) & (9) & (10) & (11) & (12) \\
\hline & Pool & 3rd & 5th & 7th & Pool & 3rd & 5 th & 7th & Pool & 3rd & 5 th & 7th \\
\hline \multicolumn{13}{|c|}{ A. \%Metco Enrolled } \\
\hline \multirow[t]{3}{*}{ Core } & -25.5 & -22.7 & -34.8 & -15.6 & -26.4 & -18.8 & -34.4 & -17.9 & -27.0 & -19.2 & -35.6 & -18.1 \\
\hline & $(8.8)$ & (17.3) & $(16.0)$ & (13.2) & $(8.9)$ & (17.9) & $(16.2)$ & $(13.0)$ & $(7.5)$ & $(15.5)$ & $(12.1)$ & (10.3) \\
\hline & [8.0] & [16.5] & [13.9] & [12.6] & [8.0] & [17.9] & [14.2] & [11.8] & & & & \\
\hline \multirow[t]{3}{*}{ Reading } & -20.4 & -21.3 & -31.4 & -14.5 & -21.2 & -16.7 & -31.0 & -16.5 & -21.6 & -16.6 & -31.6 & -16.5 \\
\hline & $(7.8)$ & $(16.2)$ & $(14.0)$ & (11.3) & $(7.9)$ & $(16.5)$ & $(13.9)$ & (11.3) & $(6.7)$ & (14.2) & $(12.0)$ & $(9.1)$ \\
\hline & [7.24] & [15.96] & [13.93] & [10.97] & [7.16] & [16.36] & [14.12] & [10.47] & & & & \\
\hline \multirow[t]{3}{*}{ Math } & -23.5 & -16.9 & -40.4 & -12.0 & -25.1 & -12.1 & -39.7 & -14.5 & -25.6 & -11.4 & -40.7 & -14.8 \\
\hline & $(10.1)$ & (19.2) & (19.7) & (14.9) & $(10.1)$ & (19.9) & (19.5) & $(14.5)$ & (8.9) & (18.5) & (15.7) & (11.4) \\
\hline & {$[9.5]$} & [20.0] & [18.9] & [14.3] & {$[9.5]$} & [21.3] & [18.2] & [13.1] & & & & \\
\hline \multirow[t]{3}{*}{ Language } & -25.0 & -29.9 & -25.2 & -13.0 & -27.0 & -31.3 & -25.7 & -16.2 & -28.1 & -33.0 & -26.7 & -16.5 \\
\hline & $(9.3)$ & (17.2) & $(17.2)$ & $(13.0)$ & $(9.5)$ & (18.0) & $(17.8)$ & (13.0) & $(7.9)$ & (15.7) & $(12.1)$ & $(10.5)$ \\
\hline & [8.5] & [16.6] & [13.7] & [12.5] & [8.5] & [18.2] & [14.1] & [12.2] & & & & \\
\hline $\mathbf{N}$ & 56 & 56 & 56 & 168 & 56 & 56 & 56 & 168 & 8159 & 2672 & 2797 & 2690 \\
\hline \multicolumn{13}{|c|}{ B. \%Metco Tested } \\
\hline \multirow[t]{3}{*}{ Core } & -22.1 & -21.8 & -28.0 & -16.9 & -23.3 & -17.7 & -29.2 & -18.9 & -23.9 & -18.1 & -30.3 & -19.3 \\
\hline & $(8.0)$ & (15.4) & (15.1) & (11.8) & $(8.1)$ & (15.9) & (15.1) & (11.8) & $(6.7)$ & (13.5) & (11.2) & $(9.5)$ \\
\hline & [7.2] & [14.6] & [12.8] & [11.8] & [7.2] & [15.6] & [13.1] & [10.9] & & & & \\
\hline \multirow[t]{3}{*}{ Reading } & -18.7 & -22.7 & -27.3 & -14.0 & -19.6 & -18.6 & -27.1 & -15.9 & -20.1 & -18.7 & -27.7 & -16.1 \\
\hline & $(7.1)$ & (14.3) & (13.1) & (10.2) & $(7.2)$ & (14.6) & (12.9) & (10.2) & (6.1) & (12.0) & (10.9) & $(8.4)$ \\
\hline & [6.7] & [14.0] & [12.8] & [10.2] & [6.5] & [14.0] & [12.8] & [9.6] & & & & \\
\hline \multirow[t]{3}{*}{ Math } & -20.7 & -19.8 & -30.2 & -14.3 & -22.7 & -15.0 & -32.0 & -16.5 & -23.2 & -14.6 & -33.0 & -17.0 \\
\hline & $(9.2)$ & (17.0) & (18.7) & (13.4) & $(9.2)$ & (17.7) & (18.2) & (13.2) & (7.8) & (14.9) & (14.4) & (10.5) \\
\hline & [8.4] & [16.5] & [17.2] & [13.5] & [8.4] & [17.1] & [16.7] & [12.2] & & & & \\
\hline \multirow[t]{3}{*}{ Language } & -19.5 & -22.0 & -19.0 & -14.2 & -21.7 & -22.6 & -21.1 & -17.1 & -22.6 & -24.1 & -22.0 & -17.6 \\
\hline & (8.5) & (15.6) & (16.1) & (11.6) & $(8.7)$ & (16.3) & (16.4) & (11.8) & (7.3) & (14.3) & (11.7) & $(9.6)$ \\
\hline & [7.8] & [15.1] & [13.3] & [11.6] & [7.8] & [16.6] & [13.5] & [11.2] & & & & \\
\hline $\mathbf{N}$ & 56 & 56 & 56 & 168 & 56 & 56 & 56 & 168 & 8159 & 2672 & 2797 & 2690 \\
\hline
\end{tabular}

Notes: Columns 1 - 4 report OLS estimates of the coefficient on the percent Metco variable in equation (1) in the text. Columns 5-8 report weighted least squares estimates, weighting by the number of observations in the relevant grade/school/year cell. Columns 9-12 report student-level OLS estimates. Standard errors are reported in parentheses and robust standard errors are reported in brackets. Standard errors in columns 9-12 are clustered by grade/school/year cell. Covariates in columns 9-12 include class size and fixed effects for school and year. Pooled models include cohort and grade fixed effects. For Columns $9-12, \mathrm{~N}$ is the number of observations in the Core regression. Panel A uses a measure of the percent Metco variable constructed from enrollment data. Panel B uses a measure of the percent Metco variable constructed from the Riverside data. Metco students are omitted from the sample used to construct the estimates in columns 9-12 but the score of Metco students are included in the peer means. 
Table 5: The Effect of Metco on the 2nd Decile of the Test Score Distribution

\begin{tabular}{|c|c|c|c|c|c|c|c|c|c|c|c|c|}
\hline \multirow[b]{2}{*}{ Subject } & \multicolumn{4}{|c|}{ Unweighted Means } & \multicolumn{4}{|c|}{ Weighted Means } & \multicolumn{4}{|c|}{ Micro Data Quantile Regression } \\
\hline & $\begin{array}{l}\text { Pool } \\
\text { (1) }\end{array}$ & $\begin{array}{l}\text { 3rd } \\
(2) \\
\end{array}$ & $\begin{array}{l}\text { 5th } \\
\text { (3) }\end{array}$ & $\begin{array}{l}\text { 7th } \\
\text { (4) }\end{array}$ & $\begin{array}{l}\text { Pool } \\
\text { (5) }\end{array}$ & $\begin{array}{l}\text { 3rd } \\
(6)\end{array}$ & $\begin{array}{l}\text { 5th } \\
(7) \\
\end{array}$ & $\begin{array}{l}\text { 7th } \\
(8)\end{array}$ & $\begin{array}{c}\text { Pool } \\
(9)\end{array}$ & $\begin{array}{l}\text { 3rd } \\
(10) \\
\end{array}$ & $\begin{array}{l}\text { 5th } \\
(11) \\
\end{array}$ & $\begin{array}{l}\text { 7th } \\
(12)\end{array}$ \\
\hline \multicolumn{13}{|c|}{ A. \%Metco Enrolled } \\
\hline Core & $\begin{array}{l}-56.9 \\
(16.8) \\
{[16.2]}\end{array}$ & $\begin{array}{l}-64.3 \\
(34.9) \\
\end{array}$ & $\begin{array}{l}-51.2 \\
(29.9)\end{array}$ & $\begin{array}{l}-46.1 \\
(26.5)\end{array}$ & $\begin{array}{l}-59.3 \\
(17.2) \\
{[16.31}\end{array}$ & $\begin{array}{l}-65.4 \\
(36.3)\end{array}$ & $\begin{array}{l}-50.7 \\
(30.4)\end{array}$ & $\begin{array}{l}-48.9 \\
(26.8)\end{array}$ & $\begin{array}{c}-55.8 \\
(18.7)\end{array}$ & $\begin{array}{l}-63.6 \\
(50.2)\end{array}$ & $\begin{array}{l}-62.9 \\
(31.9)\end{array}$ & $\begin{array}{c}-49.1 \\
(27.4)\end{array}$ \\
\hline Reading & $\begin{array}{l}-50.4 \\
(16.4) \\
{[16.7]}\end{array}$ & $\begin{array}{l}\text {-53.5 } \\
(33.4) \\
{[39.2]}\end{array}$ & $\begin{array}{l}-54.8 \\
(25.5) \\
{[25.1]}\end{array}$ & $\begin{array}{l}{[-43.9} \\
(26.6) \\
{[25.4]}\end{array}$ & $\begin{array}{l}-52.8 \\
(16.7) \\
{[16.2]}\end{array}$ & $\begin{array}{l}-49.6 \\
(33.6) \\
{[36.4]}\end{array}$ & $\begin{array}{l}-57.5 \\
(26.1) \\
{[26.8]}\end{array}$ & $\begin{array}{l}-47.6 \\
(27.3) \\
{[26.0]}\end{array}$ & $\begin{array}{l}-48.7 \\
(19.8)\end{array}$ & $\begin{array}{l}-63.5 \\
(34.1)\end{array}$ & $\begin{array}{l}-60.6 \\
(34.7)\end{array}$ & $\begin{array}{l}-37.1 \\
(39.6)\end{array}$ \\
\hline Math & $\begin{array}{l}-39.8 \\
(18.9) \\
{[19.1]}\end{array}$ & $\begin{array}{l}-38.9 \\
(38.0) \\
{[41.5]}\end{array}$ & $\begin{array}{l}-44.1 \\
(31.8) \\
{[31.3]}\end{array}$ & $\begin{array}{l}-34.0 \\
(31.7) \\
{[31.8]}\end{array}$ & $\begin{array}{l}-42.8 \\
(19.2) \\
{[18.9]}\end{array}$ & $\begin{array}{l}-31.5 \\
(39.9) \\
{[43.2]}\end{array}$ & $\begin{array}{l}-44.3 \\
(31.9) \\
{[31.8]}\end{array}$ & $\begin{array}{l}-36.1 \\
(31.3) \\
{[29.7]}\end{array}$ & $\begin{array}{l}-45.2 \\
(21.2)\end{array}$ & $\begin{array}{l}-29.0 \\
(42.4)\end{array}$ & $\begin{array}{l}-48.3 \\
(37.2)\end{array}$ & $\begin{array}{l}-24.7 \\
(41.1)\end{array}$ \\
\hline Language & $\begin{array}{l}-42.1 \\
(17.0) \\
{[15.6]}\end{array}$ & $\begin{array}{l}-53.5 \\
(36.2) \\
{[35.8]}\end{array}$ & $\begin{array}{l}-14.8 \\
(32.6) \\
{[24.7]}\end{array}$ & $\begin{array}{l}-40.4 \\
(26.2) \\
{[23.7]}\end{array}$ & $\begin{array}{l}-45.4 \\
(17.6) \\
{[16.2]}\end{array}$ & $\begin{array}{l}-55.7 \\
(38.4) \\
{[40.5]}\end{array}$ & $\begin{array}{l}-17.2 \\
(33.3) \\
{[25.8]}\end{array}$ & $\begin{array}{l}-46.4 \\
(26.8) \\
{[24.1]}\end{array}$ & $\begin{array}{l}-48.4 \\
(17.3)\end{array}$ & $\begin{array}{l}-73.7 \\
(45.0)\end{array}$ & $\begin{array}{l}-30.8 \\
(33.1)\end{array}$ & $\begin{array}{l}-37.8 \\
(27.7)\end{array}$ \\
\hline $\mathbf{N}$ & 168 & 56 & 56 & 56 & 168 & 56 & 56 & 56 & 8629 & 2798 & 2966 & 2865 \\
\hline & & & & & B. $\%$ & tco Tes & & & & & & \\
\hline Core & $\begin{array}{l}-51.4 \\
(15.3) \\
{[14.4]}\end{array}$ & $\begin{array}{l}-61.7 \\
(31.0) \\
{[31.8]}\end{array}$ & $\begin{array}{l}-37.8 \\
(28.1) \\
{[23.3]}\end{array}$ & $\begin{array}{l}-48.6 \\
(23.6) \\
{[23.1]}\end{array}$ & $\begin{array}{l}-54.4 \\
(15.7) \\
{[14.4]}\end{array}$ & $\begin{array}{c}-62.2 \\
(32.2) \\
{[32.7]}\end{array}$ & $\begin{array}{l}-40.1 \\
(28.2) \\
{[24.7]}\end{array}$ & $\begin{array}{l}-51.5 \\
(24.1) \\
{[22.1]}\end{array}$ & $\begin{array}{l}-48.6 \\
(15.5)\end{array}$ & $\begin{array}{l}-56.7 \\
(38.0)\end{array}$ & $\begin{array}{l}-43.0 \\
(31.2)\end{array}$ & $\begin{array}{l}-51.9 \\
(28.1)\end{array}$ \\
\hline Reading & $\begin{array}{l}-45.2 \\
(15.0) \\
{[15.2]}\end{array}$ & $\begin{array}{l}-58.3 \\
(29.4) \\
{[35.1]}\end{array}$ & $\begin{array}{l}-41.3 \\
(24.1) \\
{[22.0]}\end{array}$ & $\begin{array}{l}-41.1 \\
(24.0) \\
{[23.8]}\end{array}$ & $\begin{array}{l}-47.8 \\
(15.2) \\
{[14.7]}\end{array}$ & $\begin{array}{l}-54.3 \\
(29.6) \\
{[32.3]}\end{array}$ & $\begin{array}{l}-44.3 \\
(24.4) \\
{[23.5]}\end{array}$ & $\begin{array}{l}-44.6 \\
(24.9) \\
{[24.2]}\end{array}$ & $\begin{array}{l}-43.3 \\
(16.5)\end{array}$ & $\begin{array}{l}-57.5 \\
(33.8)\end{array}$ & $\begin{array}{l}-45.8 \\
(25.8)\end{array}$ & $\begin{array}{l}-31.7 \\
(32.0)\end{array}$ \\
\hline Math & $\begin{array}{l}-37.6 \\
(17.2) \\
{[17.1]}\end{array}$ & $\begin{array}{l}-48.3 \\
(33.5) \\
{[34.6]}\end{array}$ & $\begin{array}{l}-31.4 \\
(29.8) \\
{[28.7]}\end{array}$ & $\begin{array}{l}-35.3 \\
(28.5) \\
{[29.3]}\end{array}$ & $\begin{array}{l}-40.6 \\
(17.5) \\
{[16.7]}\end{array}$ & $\begin{array}{l}-41.7 \\
(35.2) \\
{[35.2]}\end{array}$ & $\begin{array}{l}-33.1 \\
(29.6) \\
{[29.2]}\end{array}$ & $\begin{array}{l}-37.8 \\
(28.4) \\
{[27.1]}\end{array}$ & $\begin{array}{l}-44.4 \\
(14.5)\end{array}$ & $\begin{array}{l}-40.5 \\
(47.1)\end{array}$ & $\begin{array}{l}-40.0 \\
(36.7)\end{array}$ & $\begin{array}{l}-31.2 \\
(33.2)\end{array}$ \\
\hline Language & $\begin{array}{l}-35.7 \\
(15.5) \\
{[14.1]}\end{array}$ & $\begin{array}{l}-43.0 \\
(32.5) \\
{[31.2]}\end{array}$ & $\begin{array}{c}-1.8 \\
(30.3) \\
{[23.4]}\end{array}$ & $\begin{array}{l}-44.5 \\
(23.3) \\
{[21.7]}\end{array}$ & $\begin{array}{l}-39.7 \\
(16.0) \\
{[14.7]}\end{array}$ & $\begin{array}{l}-44.9 \\
(34.4) \\
{[35.3]}\end{array}$ & $\begin{array}{c}-8.7 \\
(30.8) \\
{[24.1]}\end{array}$ & $\begin{array}{l}-50.1 \\
(24.1) \\
{[22.1]}\end{array}$ & $\begin{array}{r}-40.3 \\
(15.6)\end{array}$ & $\begin{array}{l}-47.4 \\
(42.8)\end{array}$ & $\begin{array}{l}-23.0 \\
(31.5)\end{array}$ & $\begin{array}{c}-49.6 \\
(29.5)\end{array}$ \\
\hline $\mathbf{N}$ & 168 & 56 & 56 & 56 & 168 & 56 & 56 & 56 & 8629 & 2798 & 2966 & 2865 \\
\hline
\end{tabular}

Notes: The table reports results analogous to those in Table 4, replacing cells means with the .2 quantile for each cell in columns $1-8$, and using quantile

regression with micro data in columns 9-12. 
Table 6: OLS Results for Non-Metco Students

\begin{tabular}{|c|c|c|c|c|c|c|c|c|}
\hline \multirow[b]{2}{*}{ Subject } & \multicolumn{4}{|c|}{ Means } & \multicolumn{4}{|c|}{ Micro Data } \\
\hline & $\begin{array}{c}\text { Pooled } \\
(1)\end{array}$ & $\begin{array}{l}\text { 3rd } \\
(2) \\
\end{array}$ & $\begin{array}{l}\text { th } \\
(3)\end{array}$ & $\begin{array}{l}7 \text { th } \\
(4)\end{array}$ & $\begin{array}{c}\text { Pooled } \\
(5)\end{array}$ & $\begin{array}{l}\text { 3rd } \\
(6)\end{array}$ & $\begin{array}{l}\text { 5th } \\
(7)\end{array}$ & $\begin{array}{l}\text { 7th } \\
(8)\end{array}$ \\
\hline \multicolumn{9}{|c|}{ A. All Non-Metco Students } \\
\hline \multirow[t]{3}{*}{ Core } & 3.2 & 1.4 & 1.6 & 6.6 & -5.2 & -1.6 & -6.5 & -3.4 \\
\hline & $(8.0)$ & $(14.8)$ & $(15.6)$ & $(12.2)$ & $(5.4)$ & $(11.4)$ & $(10.6)$ & $(7.5)$ \\
\hline & [7.5] & [14.2] & [13.7] & [12.3] & [5.9] & [10.9] & [10.2] & [8.2] \\
\hline \multirow[t]{3}{*}{ Reading } & 5.3 & -2.1 & -1.1 & 10.2 & -2.8 & -3.9 & -5.8 & 0.1 \\
\hline & $(7.1)$ & $(13.9)$ & $(13.5)$ & $(10.3)$ & $(5.5)$ & $(11.5)$ & $(10.5)$ & (8.0) \\
\hline & [6.9] & [13.9] & [13.5] & {$[10.1]$} & {$[5.1]$} & {$[9.7]$} & [11.2] & [6.9] \\
\hline \multirow[t]{3}{*}{ Math } & 4.5 & 4.7 & -0.3 & 8.3 & -4.8 & 4.5 & -11.8 & -2.9 \\
\hline & $(9.3)$ & (17.5) & (18.7) & (13.9) & (5.7) & (11.6) & (11.2) & (8.3) \\
\hline & [8.7] & [16.7] & [17.5] & [14.1] & [7.0] & [12.1] & [12.9] & [9.4] \\
\hline \multirow[t]{3}{*}{ Language } & 0.5 & -4.6 & 4.9 & 5.4 & -8.4 & -11.5 & -3.2 & -5.0 \\
\hline & (8.5) & $(14.8)$ & (16.8) & (12.0) & (5.7) & (12.1) & (11.4) & (7.8) \\
\hline & [8.1] & [14.1] & [13.9] & [12.3] & [6.6] & [11.6] & [10.2] & [8.1] \\
\hline $\mathbf{N}$ & 168 & 56 & 56 & 56 & 8146 & 2672 & 2796 & 2678 \\
\hline \multicolumn{9}{|c|}{ B. Black and Hispanic Non-Metco Students } \\
\hline \multirow[t]{3}{*}{ Core } & -33.3 & -152.4 & 39.1 & -19.9 & -12.2 & -95.7 & 5.8 & 10.0 \\
\hline & $(30.0)$ & $(64.7)$ & $(62.2)$ & $(41.9)$ & $(22.3)$ & $(50.9)$ & $(47.0)$ & $(30.2)$ \\
\hline & [33.2] & {$[60.1]$} & [69.9] & [45.6] & [23.3] & {$[53.4]$} & [42.5] & [29.3] \\
\hline \multirow[t]{3}{*}{ Reading } & -49.9 & -256.2 & 17.7 & 16.8 & -23.3 & -116.6 & -14.7 & 10.8 \\
\hline & $(28.0)$ & $(65.9)$ & $(50.4)$ & (32.9) & $(22.7)$ & $(50.0)$ & $(46.8)$ & (32.5) \\
\hline & [34.8] & [68.7] & [54.9] & [32.5] & [21.7] & [50.2] & [33.4] & [26.3] \\
\hline \multirow[t]{3}{*}{ Math } & -10.1 & -54.9 & 27.3 & -16.0 & 13.1 & 19.2 & 0.2 & 14.2 \\
\hline & (31.0) & $(66.4)$ & (69.2) & $(42.8)$ & (23.6) & $(52.1)$ & (48.2) & (33.8) \\
\hline & [33.1] & [62.2] & [78.3] & [45.9] & [25.9] & [57.2] & [50.8] & [34.1] \\
\hline \multirow[t]{3}{*}{ Language } & -34.8 & -120.8 & 41.8 & -23.0 & -15.9 & -116.2 & 35.4 & 10.5 \\
\hline & (32.2) & (58.9) & $(68.7)$ & $(48.7)$ & (22.5) & $(49.1)$ & (47.9) & (30.0) \\
\hline & [38.2] & [65.0] & [77.2] & [54.6] & [22.7] & [43.7] & [45.3] & [30.0] \\
\hline $\mathbf{N}$ & 162 & 53 & 54 & 55 & 859 & 281 & 286 & 292 \\
\hline \multicolumn{9}{|c|}{ C. Black Non-Metco Students } \\
\hline \multirow[t]{3}{*}{ Core } & -78.1 & -218.0 & 21.8 & -68.0 & -33.1 & -170.2 & 26.9 & -3.7 \\
\hline & $(32.5)$ & $(77.1)$ & (71.9) & $(45.2)$ & (28.2) & $(67.9)$ & $(60.9)$ & $(38.4)$ \\
\hline & [36.6] & [92.8] & [79.8] & [45.0] & [24.5] & {$[54.4]$} & [49.8] & [30.4] \\
\hline \multirow[t]{3}{*}{ Reading } & -66.2 & -288.2 & 14.9 & -2.4 & -29.7 & -180.5 & 20.0 & 19.2 \\
\hline & (32.9) & $(81.4)$ & $(65.5)$ & $(43.2)$ & $(29.4)$ & $(69.9)$ & $(60.7)$ & $(41.3)$ \\
\hline & [36.0] & [94.9] & {$[62.1]$} & [43.6] & [24.5] & [56.6] & [39.5] & [33.2] \\
\hline \multirow[t]{3}{*}{ Math } & -50.0 & -92.1 & 22.5 & -61.2 & -5.4 & -31.1 & 32.7 & 2.6 \\
\hline & (33.6) & (73.6) & $(72.7)$ & $(50.8)$ & $(30.0)$ & (71.2) & $(60.4)$ & $(43.1)$ \\
\hline & [37.0] & [81.0] & [81.6] & [51.9] & [28.3] & {$[66.1]$} & [55.6] & [36.5] \\
\hline \multirow[t]{3}{*}{ Language } & -102.3 & -236.6 & 0.5 & -83.4 & -47.3 & -174.6 & 29.4 & -12.4 \\
\hline & (34.7) & $(66.0)$ & (80.2) & (49.9) & (28.0) & (63.2) & (62.3) & $(37.7)$ \\
\hline & [41.0] & [65.7] & [88.9] & [52.5] & [25.0] & [52.9] & [57.8] & [32.0] \\
\hline $\mathbf{N}$ & 146 & 45 & 49 & 52 & 534 & 169 & 183 & 182 \\
\hline
\end{tabular}

Notes: The table reports OLS estimates of equation (2) using means and equation (3) using micro data. The percent Metco regressor is constructed from the Riverside testing data. Robust standard errors are reported in brackets in columns 1-4. Robust standard errors clustered by grade/school/year cell are reported in columns 5-8. Covariates for columns 1-4 include class size and fixed effects for school and year. The micro covariates include race, gender, ESL/TBE and special education status. Pooled models include grade and cohort fixed effects. $\mathrm{N}$ in columns 5-8 shows the number in the Core regression. 
Table 7

Differenced Equations for Non-Metco Students

\begin{tabular}{|c|c|c|c|c|c|c|}
\hline \multirow[b]{2}{*}{ Subject } & \multicolumn{3}{|c|}{ 3rd - 5th Difference } & \multicolumn{3}{|c|}{ 5th - 7th Difference } \\
\hline & $\begin{array}{c}\text { Pooled } \\
(1)\end{array}$ & $\begin{array}{l}\text { 3rd } \\
(2) \\
\end{array}$ & $\begin{array}{l}\text { 5th } \\
(3)\end{array}$ & $\begin{array}{c}\text { Pooled } \\
\text { (4) }\end{array}$ & $\begin{array}{l}\text { 5th } \\
(5)\end{array}$ & $\begin{array}{l}\text { 7th } \\
(6)\end{array}$ \\
\hline \multicolumn{7}{|c|}{ A. All Non-Metco Students } \\
\hline \multirow[t]{3}{*}{ Core } & 3.2 & 7.3 & -9.7 & -9.7 & -10.0 & -8.0 \\
\hline & $(14.8)$ & (15.9) & (15.3) & (11.2) & $(15.8)$ & (12.3) \\
\hline & [19.4] & [18.7] & [16.8] & [14.4] & [19.5] & {$[16.4]$} \\
\hline \multirow[t]{3}{*}{ Reading } & 6.0 & 11.9 & -2.1 & -4.4 & 7.6 & 1.1 \\
\hline & $(17.6)$ & (18.9) & (18.3) & $(12.8)$ & $(18.0)$ & (14.1) \\
\hline & [12.5] & [11.9] & [13.6] & [11.7] & [17.0] & [14.0] \\
\hline \multirow[t]{3}{*}{ Math } & -17.7 & -5.5 & -29.8 & -21.5 & -25.9 & -16.7 \\
\hline & (19.5) & (20.9) & (20.3) & $(14.6)$ & $(20.5)$ & $(16.0)$ \\
\hline & [29.5] & [30.7] & [26.2] & [18.8] & [24.7] & [19.8] \\
\hline \multirow[t]{3}{*}{ Language } & 12.3 & 1.9 & 3.9 & -1.3 & -5.1 & -5.5 \\
\hline & (18.2) & (19.5) & (18.8) & (14.3) & (20.1) & (15.7) \\
\hline & [20.8] & [24.1] & [20.6] & [18.2] & [21.8] & [19.9] \\
\hline $\mathbf{N}$ & & 1613 & & & 1615 & \\
\hline
\end{tabular}

\section{B. Black Non-Metco Students}

\begin{tabular}{lcccccc} 
Core & -240.1 & -215.7 & -169.3 & -10.9 & -57.7 & -15.0 \\
& $(99.6)$ & $(102.7)$ & $(112.4)$ & $(62.8)$ & $(81.7)$ & $(66.2)$ \\
Reading & {$[60.9]$} & {$[60.4]$} & {$[63.0]$} & {$[45.7]$} & {$[61.5]$} & {$[44.6]$} \\
& -183.1 & -194.4 & -167.9 & -7.7 & -60.3 & -9.3 \\
& $(110.4)$ & $(114.4)$ & $(125.4)$ & $(72.2)$ & $(96.4)$ & $(76.9)$ \\
Math & {$[94.3]$} & {$[99.4]$} & {$[92.5]$} & {$[46.1]$} & {$[52.0]$} & {$[43.1]$} \\
& -247.9 & -193.9 & -312.6 & -7.2 & -8.2 & -26.5 \\
& $(121.2)$ & $(123.7)$ & $(133.1)$ & $(84.4)$ & $(113.4)$ & $(90.2)$ \\
Language & {$[90.2]$} & {$[75.4]$} & {$[102.4]$} & {$[52.4]$} & {$[58.7]$} & {$[53.2]$} \\
& -202.6 & -214.6 & -143.2 & 21.4 & -39.8 & 17.9 \\
& $(123.1)$ & $(125.9)$ & $(147.5)$ & $(91.6)$ & $(118.9)$ & $(96.5)$ \\
$\mathbf{N}$ & {$[69.9]$} & {$[76.9]$} & {$[72.6]$} & {$[73.9]$} & {$[114.5]$} & {$[78.2]$} \\
\hline
\end{tabular}

Notes: The table shows estimates of equation (4) in the text. Regressions are differenced across grades 3 and 5 or across grades 5 and 7 . Estimates in columns 1 and 4 are from models that restrict the effects of percent Metco to be the same across grades. 
Table 8: OLS, Reduced Form and First-Stage Estimates for All Non-Metco 3rd Graders

\begin{tabular}{|c|c|c|c|c|c|c|c|c|c|c|c|c|}
\hline & \multicolumn{12}{|c|}{ Dependent Variable } \\
\hline & \multicolumn{3}{|c|}{ Core } & \multicolumn{3}{|c|}{ Reading } & \multicolumn{3}{|c|}{ Math } & \multicolumn{3}{|c|}{ Language } \\
\hline & (1) & $(2)$ & (3) & (4) & (5) & (6) & (7) & (8) & (9) & (10) & (11) & (12) \\
\hline \multicolumn{13}{|c|}{ A. OLS } \\
\hline $\begin{array}{l}\text { \# Metco } \\
\text { in class }\end{array}$ & $\begin{array}{c}0.59 \\
(0.63)\end{array}$ & $\begin{array}{c}0.16 \\
(0.61)\end{array}$ & $\begin{array}{l}-0.15 \\
(0.62)\end{array}$ & $\begin{array}{c}0.37 \\
(0.62)\end{array}$ & $\begin{array}{l}0.08 \\
(0.61)\end{array}$ & $\begin{array}{l}-0.18 \\
(0.62)\end{array}$ & $\begin{array}{c}0.59 \\
(0.64)\end{array}$ & $\begin{array}{c}0.34 \\
(0.63)\end{array}$ & $\begin{array}{c}0.06 \\
(0.63)\end{array}$ & $\begin{array}{l}-0.018 \\
(0.66)\end{array}$ & $\begin{array}{l}-0.34 \\
(0.65)\end{array}$ & $\begin{array}{l}-0.61 \\
(0.65)\end{array}$ \\
\hline & {$[0.60]$} & [0.63] & {$[0.71]$} & {$[0.50]$} & [0.52] & {$[0.60]$} & {$[0.66]$} & [0.65] & {$[0.73]$} & {$[0.65]$} & {$[0.67]$} & \\
\hline $\begin{array}{l}\text { Non-Metco } \\
\text { class size }\end{array}$ & $\begin{array}{c}0.66 \\
(0.22) \\
{[0.22]}\end{array}$ & & -0.53 & $\begin{array}{c}0.58 \\
(0.22) \\
{[0.21]}\end{array}$ & & -0.53 & $\begin{array}{c}0.37 \\
(0.22) \\
{[0.25]}\end{array}$ & & -0.53 & $\begin{array}{c}0.66 \\
(0.23) \\
{[0.21]}\end{array}$ & & -0.53 \\
\hline $\begin{array}{l}\text { Non-Metco } \\
\text { enrollment }\end{array}$ & $\begin{array}{l}-0.033 \\
(0.067) \\
{[0.076]}\end{array}$ & & $\begin{array}{l}-0.038 \\
(0.067) \\
{[0.077]}\end{array}$ & $\begin{array}{c}-0.0029 \\
(0.067) \\
{[0.060]}\end{array}$ & & $\begin{array}{c}-0.0042 \\
(0.067) \\
{[0.061]}\end{array}$ & $\begin{array}{l}-0.047 \\
(0.068) \\
{[0.084]}\end{array}$ & & $\begin{array}{l}-0.049 \\
(0.069) \\
{[0.084]}\end{array}$ & $\begin{array}{c}0.012 \\
(0.070) \\
{[0.080]}\end{array}$ & & $\begin{array}{l}0.0089 \\
(0.071) \\
{[0.081]}\end{array}$ \\
\hline \multicolumn{13}{|c|}{ B. First-Stage - Dependent Variable is Number Metco in Class } \\
\hline Instrument & $\begin{array}{c}0.92 \\
(0.034) \\
{[0.18]}\end{array}$ & $\begin{array}{c}0.88 \\
(0.030) \\
{[0.16]}\end{array}$ & $\begin{array}{c}0.87 \\
(0.030) \\
{[0.17]}\end{array}$ & & & & & & & & & \\
\hline $\begin{array}{l}\text { Non-Metco } \\
\text { class size }\end{array}$ & $\begin{array}{c}0.021 \\
(0.0064) \\
{[0.040]}\end{array}$ & & & & & & & & & & & \\
\hline $\begin{array}{l}\text { Non-Metco } \\
\text { enrollment }\end{array}$ & $\begin{array}{c}0.0014 \\
(0.0018) \\
{[0.016]}\end{array}$ & & $\begin{array}{c}0.0016 \\
(0.0018) \\
{[0.016]}\end{array}$ & & & & & & & & & \\
\hline \multicolumn{13}{|c|}{ C. Reduced Form } \\
\hline Instrument & $\begin{array}{l}-0.069 \\
(1.22) \\
{[1.39]}\end{array}$ & $\begin{array}{l}-1.50 \\
(1.09) \\
{[1.33]}\end{array}$ & $\begin{array}{l}-2.67 \\
(1.10) \\
{[1.60]}\end{array}$ & $\begin{array}{c}0.28 \\
(1.25) \\
{[1.01]}\end{array}$ & $\begin{array}{l}-1.10 \\
(1.11) \\
{[1.02]}\end{array}$ & $\begin{array}{l}-2.36 \\
(1.12) \\
{[1.32]}\end{array}$ & $\begin{array}{c}0.37 \\
(1.26) \\
{[1.63]}\end{array}$ & $\begin{array}{l}-0.51 \\
(1.12) \\
{[1.41]}\end{array}$ & $\begin{array}{l}-1.64 \\
(1.13) \\
{[1.63]}\end{array}$ & $\begin{array}{l}-0.43 \\
(1.31) \\
{[1.53]}\end{array}$ & $\begin{array}{l}-1.85 \\
(1.16) \\
{[1.49]}\end{array}$ & $\begin{array}{l}-3.13 \\
(1.17) \\
{[1.75]}\end{array}$ \\
\hline $\begin{array}{l}\text { Non-Metco } \\
\text { class size }\end{array}$ & $\begin{array}{c}0.61 \\
(0.24) \\
{[0.26]}\end{array}$ & & -0.53 & $\begin{array}{c}0.59 \\
(0.24) \\
{[0.24]}\end{array}$ & & -0.53 & $\begin{array}{c}0.36 \\
(0.24) \\
{[0.30]}\end{array}$ & & -0.53 & $\begin{array}{c}0.62 \\
(0.25) \\
{[0.24]}\end{array}$ & & -0.53 \\
\hline $\begin{array}{l}\text { Non-Metco } \\
\text { enrollment }\end{array}$ & $\begin{array}{l}-0.029 \\
(0.067) \\
{[0.078]}\end{array}$ & & $\begin{array}{r}-0.0209 \\
(0.067) \\
{[0.073]}\end{array}$ & $\begin{array}{c}-0.0020 \\
(0.067) \\
{[0.062]}\end{array}$ & & $\begin{array}{l}0.0087 \\
(0.067) \\
{[0.058]}\end{array}$ & $\begin{array}{l}-0.045 \\
(0.069) \\
{[0.086]}\end{array}$ & & $\begin{array}{l}-0.037 \\
(0.069) \\
{[0.082]}\end{array}$ & $\begin{array}{c}0.015 \\
(0.07) \\
{[0.080]}\end{array}$ & & $\begin{array}{c}0.025 \\
(0.071) \\
{[0.076]}\end{array}$ \\
\hline $\mathbf{N}$ & & 2672 & & & 2773 & & & 2716 & & & 2763 & \\
\hline
\end{tabular}


Table 9: 2SLS Estimates for Non-Metco 3rd Graders with Number Metco and Non-Metco Class Size Endogenous

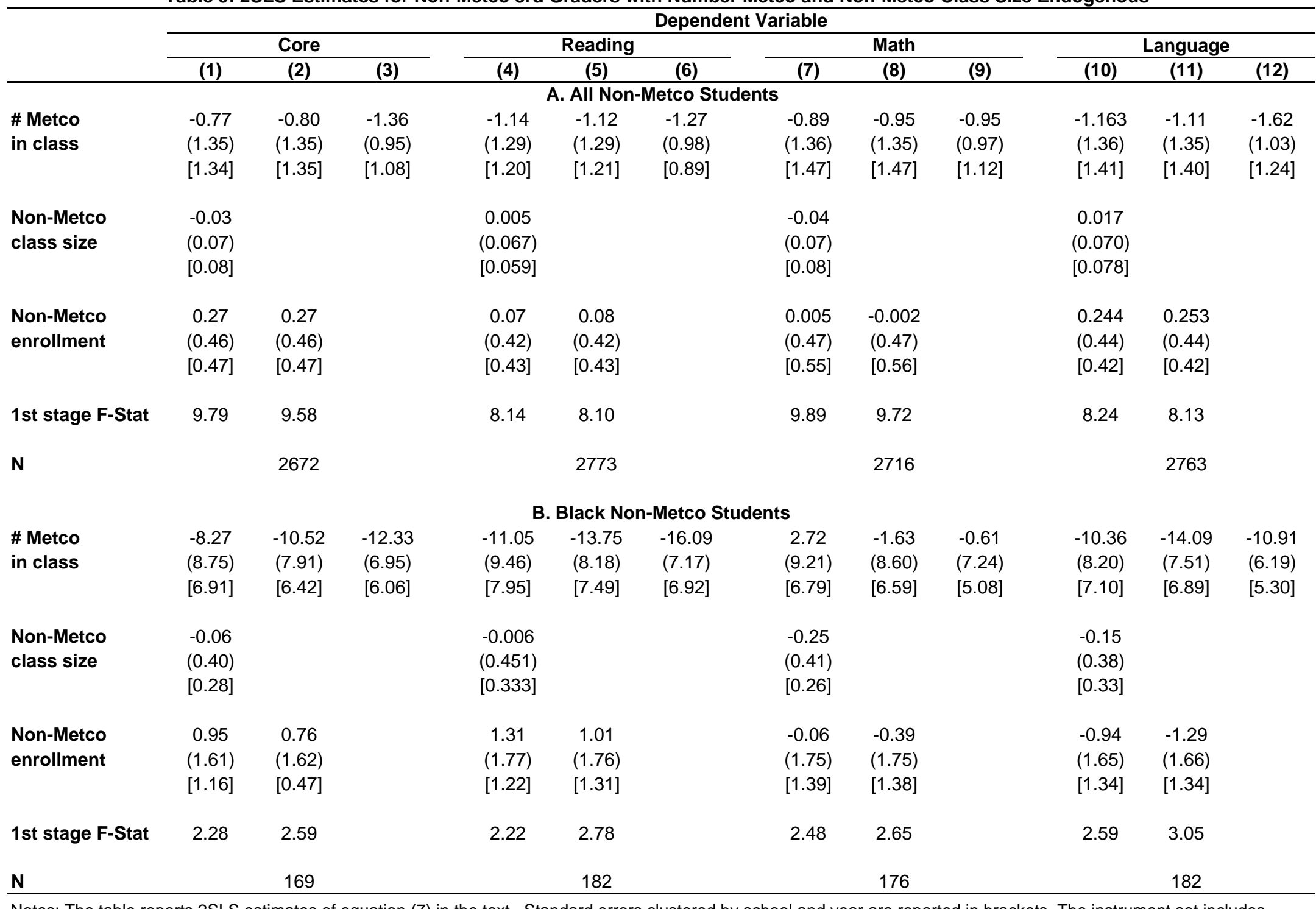

Notes: The table reports 2SLS estimates of equation (7) in the text. Standard errors clustered by school and year are reported in brackets. The instrument set includes a linear term for predicted non-Metco class size and the following six indicator variables : $1(24<=$ pclass $<25) 1(23<=$ pclass $<24), 1(22<=$ pclass $<23), 1(21<=$ pclass $<22)$, $1(20<=$ pclass $<21), 1(19<=$ pclass $<20)$. The 1 st stage F-stat refers to the F-statistic for the vector of instruments in the first stage. The F-statistic uses clustered standard errors. 
Table 10a

OLS Results for Male Non-Metco Students

\begin{tabular}{|c|c|c|c|c|c|c|c|c|}
\hline \multirow[b]{2}{*}{ Subject } & \multicolumn{4}{|c|}{ Means } & \multicolumn{4}{|c|}{ Micro Data } \\
\hline & $\begin{array}{c}\text { Pool } \\
\text { (1) }\end{array}$ & $\begin{array}{l}\text { 3rd } \\
(2)\end{array}$ & $\begin{array}{l}\text { 5th } \\
(3)\end{array}$ & $\begin{array}{l}\text { 7th } \\
(4) \\
\end{array}$ & $\begin{array}{c}\text { Pool } \\
\text { (5) }\end{array}$ & $\begin{array}{c}\text { 3rd } \\
(6) \\
\end{array}$ & $\begin{array}{c}\text { 5th } \\
(7)\end{array}$ & $\begin{array}{l}\text { 7th } \\
(8) \\
\end{array}$ \\
\hline \multicolumn{9}{|c|}{ A. All Male Non-Metco Students } \\
\hline \multirow[t]{3}{*}{ Core } & 7.7 & -1.9 & 8.3 & 16.7 & 2.5 & -4.2 & 5.5 & 8.1 \\
\hline & $(10.6)$ & $(19.4)$ & $(24.6)$ & $(15.3)$ & $(7.8)$ & $(16.6)$ & $(15.4)$ & $(10.9)$ \\
\hline & {$[8.8]$} & {$[18.7]$} & [23.0] & {$[12.7]$} & [8.0] & {$[16.7]$} & {$[16.5]$} & [11.5] \\
\hline \multirow[t]{3}{*}{ Reading } & 9.2 & -11.3 & 5.8 & 22.2 & 2.8 & -10.5 & 6.3 & 11.1 \\
\hline & (9.8) & $(17.8)$ & (22.2) & $(14.0)$ & $(7.8)$ & $(16.9)$ & $(14.9)$ & $(11.3)$ \\
\hline & [9.0] & [17.2] & [22.7] & [10.8] & [7.6] & [13.8] & [17.3] & [10.4] \\
\hline \multirow[t]{3}{*}{ Math } & 0.4 & -7.7 & -5.9 & 10.4 & -4.0 & -7.3 & -12.1 & 5.3 \\
\hline & (10.9) & (20.5) & $(24.4)$ & (16.1) & $(8.1)$ & $(16.4)$ & $(16.0)$ & (12.1) \\
\hline & [8.8] & [19.2] & [21.3] & [13.6] & [8.0] & [16.4] & [15.1] & [11.4] \\
\hline \multirow[t]{3}{*}{ Language } & 9.0 & -7.0 & 21.8 & 18.4 & 2.4 & -9.3 & 16.4 & 8.3 \\
\hline & (11.7) & (23.2) & (25.3) & (15.8) & $(8.4)$ & $(18.0)$ & (16.8) & (11.7) \\
\hline & {$[9.8]$} & [21.3] & [22.4] & [14.1] & [8.9] & [18.9] & [16.0] & [12.3] \\
\hline $\mathbf{N}$ & 168 & 56 & 56 & 56 & 4086 & 1322 & 1395 & 1369 \\
\hline
\end{tabular}

\section{B. Black Male Non-Metco Students}

\begin{tabular}{lcccccccc} 
Core & -115.4 & -163.4 & -98.5 & -112.1 & -26.0 & -155.6 & 69.4 & -31.3 \\
& $(52.7)$ & $(129.1)$ & $(133.2)$ & $(80.8)$ & $(46.2)$ & $(128.8)$ & $(130.0)$ & $(57.2)$ \\
\multirow{2}{*}{ Reading } & {$[56.6]$} & {$[128.7]$} & {$[145.2]$} & {$[77.5]$} & {$[41.0]$} & {$[106.2]$} & {$[119.6]$} & {$[51.7]$} \\
& -68.6 & -152.5 & -117.4 & -47.8 & -14.7 & -188.8 & 44.9 & -3.1 \\
& $(47.7)$ & $(145.4)$ & $(111.3)$ & $(69.3)$ & $(46.3)$ & $(132.5)$ & $(120.9)$ & $(58.7)$ \\
\multirow{4}{*}{ Math } & {$[49.4]$} & {$[121.5]$} & {$[114.6]$} & {$[71.7]$} & {$[37.4]$} & {$[102.8]$} & {$[97.4]$} & {$[54.8]$} \\
& -74.0 & 47.3 & -119.6 & -63.5 & 2.2 & 80.3 & 31.6 & -1.6 \\
& $(53.5)$ & $(127.3)$ & $(118.7)$ & $(82.9)$ & $(47.4)$ & $(120.1)$ & $(120.7)$ & $(62.5)$ \\
Language & {$[53.7]$} & {$[114.9]$} & {$[133.3]$} & {$[73.0]$} & {$[43.6]$} & {$[122.8]$} & {$[118.3]$} & {$[52.7]$} \\
& -137.7 & -101.4 & -34.0 & -150.8 & -46.4 & -90.3 & 92.7 & -55.2 \\
& $(54.5)$ & $(124.1)$ & $(131.9)$ & $(87.9)$ & $(45.2)$ & $(106.3)$ & $(124.0)$ & $(58.9)$ \\
$\mathbf{N}$ & {$[56.2]$} & {$[121.4]$} & {$[154.0]$} & {$[83.2]$} & {$[42.6]$} & {$[129.3]$} & {$[125.7]$} & {$[54.9]$} \\
\hline
\end{tabular}

Notes: The table reports estimates analogous to those in Table 6, for the sample of boys only. 
Table 10b

OLS Results for Female Non-Metco Students

\begin{tabular}{|c|c|c|c|c|c|c|c|c|}
\hline \multirow[b]{2}{*}{ Subject } & \multicolumn{4}{|c|}{ Means } & \multicolumn{4}{|c|}{ Micro Data } \\
\hline & $\begin{array}{l}\text { Pool } \\
(1)\end{array}$ & $\begin{array}{l}\text { 3rd } \\
(2) \\
\end{array}$ & $\begin{array}{l}\text { 5th } \\
(3)\end{array}$ & $\begin{array}{l}\text { 7th } \\
(4)\end{array}$ & $\begin{array}{c}\text { Pool } \\
(5) \\
\end{array}$ & $\begin{array}{l}\text { 3rd } \\
(6)\end{array}$ & $\begin{array}{l}\text { 5th } \\
(7)\end{array}$ & $\begin{array}{l}7 \text { th } \\
(8)\end{array}$ \\
\hline \multicolumn{9}{|c|}{ A. All Female Non-Metco Students } \\
\hline \multirow[t]{3}{*}{ Core } & -1.4 & 8.7 & -5.5 & -3.5 & -11.6 & 2.9 & -19.4 & -15.1 \\
\hline & $(10.0)$ & $(19.5)$ & $(19.4)$ & $(15.8)$ & $(7.4)$ & $(15.7)$ & $(14.6)$ & $(10.3)$ \\
\hline & [10.9] & [21.7] & [14.3] & [17.2] & {$[7.8]$} & [12.6] & [10.7] & [10.6] \\
\hline \multirow[t]{3}{*}{ Reading } & 1.2 & 11.0 & -7.0 & -3.2 & -7.3 & 5.5 & -19.6 & -11.2 \\
\hline & $(9.7)$ & $(19.8)$ & $(18.0)$ & $(15.9)$ & $(7.7)$ & $(15.8)$ & $(14.9)$ & $(11.4)$ \\
\hline & {$[10.0]$} & [20.8] & [15.3] & [16.8] & [6.9] & [11.2] & [11.8] & [10.8] \\
\hline \multirow[t]{3}{*}{ Math } & 6.3 & 18.3 & -0.8 & 4.9 & -3.6 & 15.3 & -11.0 & -10.5 \\
\hline & (11.6) & (20.9) & (23.0) & (18.1) & (8.0) & (16.5) & (15.9) & (11.5) \\
\hline & [11.9] & [22.4] & [20.4] & [18.8] & [9.1] & [14.1] & [15.2] & [11.6] \\
\hline \multirow[t]{3}{*}{ Language } & -6.9 & 1.2 & -7.4 & -7.0 & -18.1 & -8.8 & -23.0 & -19.3 \\
\hline & (10.5) & (19.5) & (21.9) & (15.5) & $(7.7)$ & (16.3) & (15.4) & (10.5) \\
\hline & [11.8] & [20.3] & [19.1] & [17.0] & [9.0] & [13.9] & [15.4] & [11.0] \\
\hline \multirow[t]{2}{*}{$\mathbf{N}$} & 168 & 56 & 56 & 56 & 4060 & 1350 & 1401 & 1309 \\
\hline & \multicolumn{8}{|c|}{ B. Black Female Non-Metco Students } \\
\hline \multirow[t]{2}{*}{ Core } & $\begin{array}{l}-42.9 \\
(49.6)\end{array}$ & $\begin{array}{l}-340.2 \\
(120.9)\end{array}$ & $\begin{array}{c}31.5 \\
(88.9)\end{array}$ & $\begin{array}{c}40.9 \\
(68.6)\end{array}$ & $\begin{array}{l}-37.8 \\
(39.6)\end{array}$ & $\begin{array}{r}-197.1 \\
(98.9)\end{array}$ & $\begin{array}{c}0.8 \\
(69.4)\end{array}$ & $\begin{array}{c}6.6 \\
(63.7)\end{array}$ \\
\hline & [55.0] & [137.7] & [93.1] & [66.4] & [38.0] & [107.4] & [53.3] & [54.3] \\
\hline \multirow[t]{3}{*}{ Reading } & -37.0 & -341.6 & 74.5 & 63.4 & -40.7 & -178.7 & -0.4 & 17.4 \\
\hline & (52.5) & (127.1) & (91.3) & $(70.0)$ & (42.7) & (102.3) & (76.4) & (70.8) \\
\hline & [57.6] & [135.8] & [92.9] & [66.1] & [39.2] & [104.1] & [57.7] & [45.3] \\
\hline \multirow[t]{3}{*}{ Math } & -36.5 & -204.3 & 39.6 & -10.4 & -15.4 & -74.8 & 7.2 & -44.0 \\
\hline & (45.3) & (109.2) & (69.9) & (72.1) & $(42.6)$ & (104.5) & (70.8) & $(71.2)$ \\
\hline & [47.6] & [116.2] & [70.2] & [64.9] & [41.5] & [117.6] & [57.3] & [62.9] \\
\hline \multirow[t]{3}{*}{ Language } & -28.0 & -360.9 & 22.0 & 82.1 & -31.6 & -195.2 & 0.2 & 39.7 \\
\hline & (49.8) & $(114.4)$ & $(91.6)$ & (66.5) & $(40.2)$ & (96.6) & $(74.4)$ & $(60.5)$ \\
\hline & [55.1] & [132.6] & [94.7] & [68.0] & [38.2] & [98.6] & [61.5] & [56.5] \\
\hline $\mathbf{N}$ & 124 & 41 & 40 & 43 & 258 & 88 & 90 & 80 \\
\hline
\end{tabular}

Notes: The table reports estimates analogous to thise in Table 6, for the sample of girls only. 


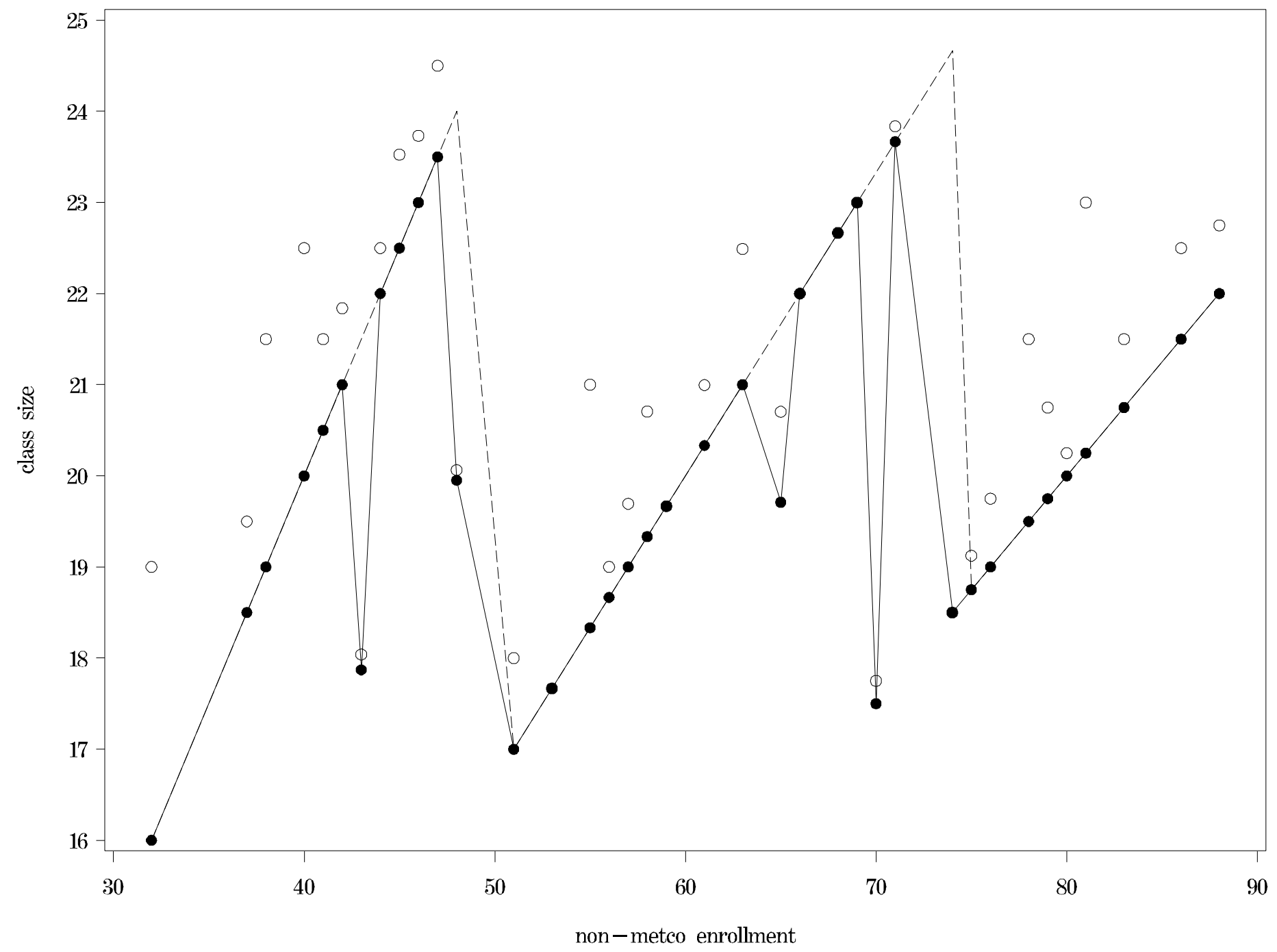

Figure 1. Predicted and actual class size (circles $=$ size with METCO pupils included). Data for Brookline 3rd graders. 


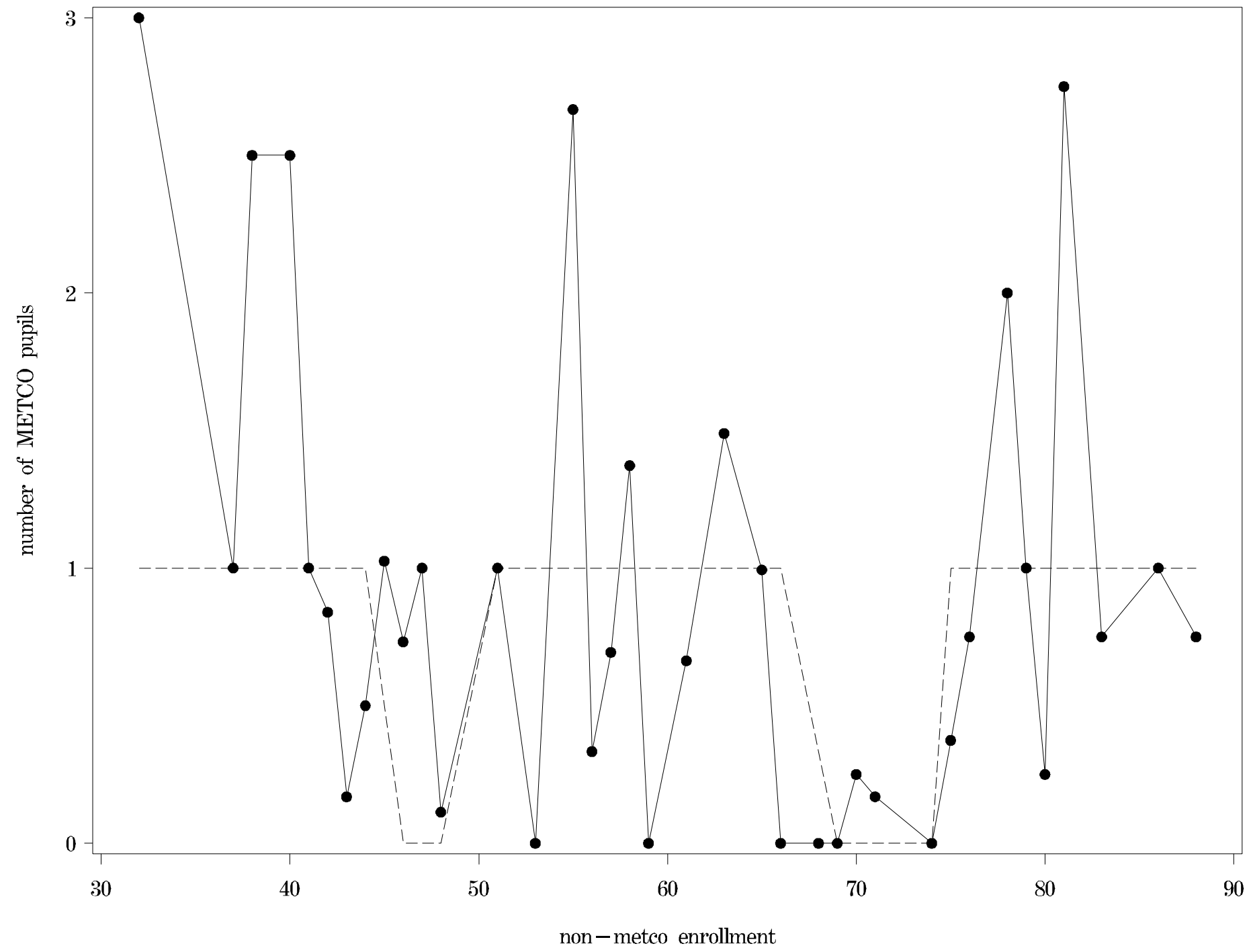

Figure 2. Predicted and actual number of METCO pupils per class. 